\title{
TEKSTYLIA I PIECZECIE. O RELACJACH POMIĘDZY PRODUKCJĄ WŁÓKIENNICZĄ A PRAKTYKAMI STEMPLOWANIA W GRECJI EPOKI BRAZZU ORAZ O ZUPEŁNIE NOWYCH DANYCH Z ODCISKÓW GLINIANYCH PIECZĘCI
}

\author{
TEXTILES AND SEALS: ABOUT THE RELATIONSHIP BETWEEN TEXTILE \\ PRODUCTION AND SEALING PRACTICES IN BRONZE AGE GREECE \\ AND THE NEW EVIDENCE FROM THE CASTS OF TEXTILE \\ IMPRESSIONS ON CLAY
}

\begin{abstract}
This contribution discusses the evidence of textile impressions preserved on the undersides of clay sealings from Bronze Age Greece. A collection of modern casts taken from these sealings, stored in the Corpus der minoischen und mykenischen Siegel in Heidelberg, is currently being analyzed by the author. The assumed reliability of textile impressions as a source of knowledge about the qualities of actual textiles and raw materials used to produce them has been verified by a series of archaeological experiments and comparative analysis of modern raw materials of various origin. Results of the analysis of 199 casts from two Aegean sites: Lerna in Argolid and Phaistos on Crete, have provided new evidence for technical uses of textile and organic products in the daily storage routine and sealing practices, as well as for the specific parameters of threads, cords, and fabrics impressed on clay. Due to the relatively large number of textile imprints, it is possible, for the first time, to make site-specific comparisons of textile production on the basis of products and to track technical developments in textile manufacturing throughout the Aegean Bronze Age.
\end{abstract}

KEY WORDS: Greece, Bronze Age, textile production, seals, sealing practices, textile imprints on clay

\section{TEKSTYLIA I PIECZECIE: WPROWADZENIE}

Chociaż warunki klimatyczne w Grecji nie sprzyjają przetrwaniu materiałów organicznych i liczba tzw. tekstyliów archeologicznych, czyli wyrobów tekstylnych odkrywanych podczas wykopalisk, jest niewielka (cf. Skals et al. 2015), multidyscyplinarne analizy szeregu źródeł pośrednich pozwoliły na odtworzenie kluczowej roli produkcji włókienniczej w gospodarkach kultur egejskich (np. Barber 1991; Tzachili 1997; Burke 2010; Nosch, Laffineur 2012; Harlow et al. 2014; Shaw, Chapin 2016; †Cutler 2021). Liczne pozostałości narzędzi włókienniczych umożliwiają szacunkowe określenie parametrów przędzionych nitek, a następnie tkanin (Andersson Strand, Nosch 2015), rozmieszczenie narzędzi wskazywać może na skalę i organizację produkcji (Ulanowska, Siennicka 
2018), a także na procesy społeczne towarzyszące przekazywaniu umiejętności wytwórczych (†Cutler 2019). Pozostałości miejsc pracy dowodzą specjalizacji rzemieślniczej oraz, w przypadku farbiarni, zaawansowanych umiejętności barwienia chemicznego z wykorzystaniem purpury ze ślimaków z gatunku rozkolców (Brogan et al. 2012; Koh et al. 2016). Ikonografia, zwłaszcza malarstwo ścienne, umożliwia studia nad strojem (Crowley 2012; Jones 2015; Shaw, Chapin 2016), znaczeniem ubiorów w kulcie (Boloti 2017) oraz, do pewnego stopnia, techniczną analizę tkanin ukazanych na freskach (Ulanowska 2018). Tabliczki z pismem linearnym B dokumentują niemalże przemysłową skalę produkcji kontrolowanej przez pałace mykeńskie, $\mathrm{z}$ dziesiątkami ton wełny i lnu przetwarzanymi rocznie przez setki pracowników tekstylnych. Zapisy rejestrują wszystkie etapy produkcji: od hodowli owiec i uprawy lnu, do redystrybucji gotowych już tkanin i ich prawdopodobnego użycia w charakterze środka płatniczego (cf. Killen 2007; Burke 2010; Nosch 2012; Rougemont 2014). Lepsze zrozumienie złożoności chaîne opératoire włókiennictwa i jej powszechnej obecności w życiu codziennym umożliwiają wreszcie badania etnograficzne i archeologia eksperymentalna (np. Andersson Strand, Nosch 2015; Ulanowska 2016).

Wspomniana złożoność chaîne opératoire włókiennictwa sprawiała, że wytwórcy musieli posiadać szereg różnorodnych umiejętności, a organizacja pracy, nawet w produkcji przydomowej, wymagała dalekosiężnego planowania oraz zdolności zarządczych. Nie jest zatem dziwne, że produkcja włókiennicza podlegała bardzo wcześnie praktykom administracyjnym, takim jak, potwierdzone od wczesnego okresu epoki brązuㄹ, ważenie wełny (Michailidou 1990, 416; Cutler 2016, 176; Alberti 2017) oraz, sugerowane graficzną formą znaków, odniesienia do produkcji włókienniczej w dwóch nieodczytanych pismach egejskich: kreteńskim piśmie hieroglificznym i linearnym A (Militello 2007; Burke 2010; del Freo et al. 2010; Nosch, Ulanowska 2021). Wśród tych wczesnych praktyk, znalazła się także praktyka stemplowania narzędzi włókienniczych, która jednak, jak dotąd, nie stała się przedmiotem szczególniejszej uwagi

1 Tradycyjnie epoka brązu w Grecji dzielona jest na trzy główne okresy: wczesny (3100-2100/2050 p.n.e.), środkowy (2100/2050-1700/1675 p.n.e.) i późny (1700/16751075/1050 p.n.e.), za Manning 2010, Table 2.2. Fazy epoki brązu na lądzie greckim określane są jako okres helladzki, na Krecie - minojski i na Cykladach - cykladzki. badawczej ani ze strony archeologów włókiennictwa, ani specjalistów od gliptyki egejskiej (cf. Ulanowska 2020a).

Praktyki stemplowania znane były we wszystkich kulturach egejskich od wczesnego okresu epoki brązu, aż po jej schyłek, choć nieprzerwane użycie pieczęci poświadczone jest wyłącznie na Krecie (Krzyszkowska 2005). Licznie zachowane pieczęcie oraz ich odciski w glinie od ponad 100 lat stanowią cenne źródło informacji na temat szeregu aspektów życia, od praktyk administracyjnych do symbolicznego znaczenia pieczęci jako talizmanów, apotropajonów, ozdób oraz znaczników społecznego statu$\mathrm{su}^{2}$. Szczególną rolę pełni bogata ikonografia, która ze względu na to, że wiele pieczęci zachowało się w całości, stanowi „okno” pozwalające na kompletny ogląd obrazowania przez egejskich gliptyków w ponad 1000-letniej longue durée, nawet jeśli nieznany jest klucz do odczytywania większości zachowanych przedstawień. Ikonograficzne odniesienia do produkcji włókienniczej, choć sygnalizowane wcześniej (Panagiotakopulu et al. 1997; Burke 1997; 2010; Ulanowska 2017), również nie doczekały się, jak dotąd, kompleksowego i systematycznego opracowania (cf. Ulanowska 2020b).

Ostatnią relacją pomiędzy produkcją włókienniczą a praktykami stemplowania jest techniczne użycie tekstyliów w praktykach stemplowania, odzwierciedlone w licznych odciskach wyrobów z materiałów organicznych: rozmaitych nitkach, sznurkach, rzemykach i tkaninach, które zachowały się na spodach glinianych pieczęci nakładanych na sznurkowe zamknięcia drzwi, gałki od drzwi i skrzynek, zabezpieczone tkaniną i sznurkiem wylewy naczyń, pokrywy koszy czy niewielkie pakiety ze złożonego kilkukrotnie pergaminu owijanego cienkimi nitkami. Znaczna część tego cennego materiału, zadokumentowana w formie współczesnych odcisków i odlewów w plastelinie i silikonie, jest przechowywana obecnie

2 Ogólne podsumowanie stanu badań na temat gliptyki egejskiej, cf. Younger 1991 (bibliografia do roku 1989); Krzyszkowska 2005, 311-344; Sphragis, biliografia online gliptyki egejskiej stworzona przez J. Youngera, http:// people.ku.edu/ jyounger/Spharagis/, dostęp 7.12.2020; Weingarten 2018; Younger 2018. Korpusy pieczęci egejskich z wprowadzeniami, cf. CMS I-XIII; CMS Beihefte 1-10; Palaima 1990; Krzyszkowska 2005; CMS Arachne: ogólnodostępna baza danych zawierająca większość materiałów ilustracyjnych oraz opisów z papierowych tomów CMS, https://arachne.uni-koeln.de/drupal/?q=en/node/196, dostęp: 7.12.2020. 
w Corpus der minoischen und mykenischen Siegel Archiv (dalej CMS) na Uniwersytecie w Heidelbergu. Podobnie, jak w przypadku stemplowanych narzędzi i ikonografii produkcji włókienniczej, obecność odcisków sznurków i nitek została zaważona i odnotowana w publikacjach (np. Fiandra 1968; Müller 1997; 1999; 2002; 2004; Müller, Pini 1997; Panagiotopoulos 2014), łącznie z próbami identyfikacji surowca (Müller, Pini 1997, 67-69; Müller 1999, 380-388). Jednakże, z wyjątkiem kilku odcisków z wczesnego okresu epoki brązu z Geraki i Lerna (Weingarten et al. 1999; Weingarten 2000; Maran, Kostoula 2014, 149, przypis 18), nie powstała, jak dotąd, analiza techniczna odciśniętych wyrobów, która byłaby zgodna ze standardami przyjętymi $\mathrm{w}$ archeologii włókiennictwa. Nie podjęto także próby porównania wyrobów z różnych stanowisk, która mogłaby wskazywać na zmiany w doborze surowców i produktów używanych w praktykach stemplowania i magazynowania oraz ewentualne zmiany technik włókienniczych. Znaczna liczba odcisków tekstyliów na spodach glinianych pieczęci, w tym odcisków z dobrze datowanym kontekstem archeologicznym, stwarza taką możliwość po raz pierwszy ${ }^{3}$. Wyjaśnić bowiem należy, że ograniczony zbiór tekstyliów archeologicznych sprawia, iż wyroby pochodzące $\mathrm{z}$ całej epoki brązu postrzegane są jako technologicznie podobne, jeśli chodzi o wybór surowca (len), cechy nitek (S-skrętne) i sploty (płócienny, cf. Spantidaki, Moulherat 2012).

Zasygnalizowane powyżej luki w wiedzy ma za zadanie częściowo wypełnić projekt badawczy pt. Tekstylia i pieczęcie. Relacje pomiędzy produkcja włókiennicza a pieczęciami i praktykami stemplowania $w$ Grecji epoki brazu, realizowany na Wydziale Archeologii Uniwersytetu Warszawskiego ${ }^{4}$. Celem projektu jest odtworzenie znaczenia relacji pomiędzy produkcją włókienniczą a sfragistycznym i symbolicznym użyciem pieczęci, poprzez analizę trzech głównych kategorii wspomnianych powyżej źródeł: 1) stemplowanych narzędzi włókienniczych, 2) ikonograficznych odniesień do produkcji włókienniczej w gliptyce oraz 3) odcisków wyrobów tekstylnych jakie zachowały się na spodach glinianych pieczęci. Celem niniejszego artykułu jest szersze przedstawie-

3 W bazie danych „Tekstylia i pieczęcie” znajdują się obecnie 227 nowożytne odciski i odlewy z odciśniętymi wyrobami z materiałów organicznych.

4 Projekt finansowany przez program NCN SONATA 13, nr ref. 2017/26/D/HS3/00145, 2018-2021 r., http://texti leseals.uw.edu.pl/pl/, dostęp: 7.12.2020. nie potencjału poznawczego odcisków tekstyliów na spodach pieczęci wraz z propozycją metodyki ich badań. Omówione poniżej przykłady pochodzą z sukcesywnie przeze mnie badanej, unikatowej kolekcji nowożytnych odcisków i odlewów w archiwum CMS w Heidelbergu ${ }^{5}$.

\section{ODCISKI NITEK, SZNURKÓW I TKANIN JAKO ŹRÓDŁO WIEDZY O PARAMETRACH TECHNICZNYCH TEKSTYLIÓW}

Odciski rozmaitych wyrobów tekstylnych w glinie powszechnie uważane są za cenne źródło wiedzy o oryginalnych produktach, choć informacje, jakich mogą dostarczyć, ograniczone są zarówno samą naturą odcisków, jak i ich czytelnością. Jednym z rodzajów odcisków tekstylnych w glinie są te zachowane na spodach glinianych pieczęci, znane $\mathrm{z}$ wielu stanowisk archeologicznych z epoki brązu, z poświadczonymi praktykami stemplowania (np. Weingarten 2000; Weingarten et al. 1999; Laurito 2007a; 2007b; Maran, Kostoula 2014; Andersson Strand et al. 2017; Vakirtzi et al. 2018). Różnią się one od odcisków na spodach naczyń przede wszystkim rozmaitością odciskanych wyrobów, które odzwierciedlają przekrój tekstyliów technicznych stosowanych w praktykach magazynowania, zabezpieczania i autoryzowania dostępu do pomieszczeń i produktów, oznaczania własności lub cech towarów. W Grecji epoki brązu są to więc luźno skręcone włókna, cienkie nitki, różnych średnic sznurki, tasiemki, rzemyki oraz tkaniny, ale także skórzane worki, koszyki, maty, plecionki, liście, drewniane kołki od drzwi i drzwiczek lub kołki stanowiące zamknięcia worków, belki drzwi oraz pergaminowe pakiety (ryc. 1, cf. Krzyszkowska 2005 dla przekrojowego opisu praktyk stemplowania).

5 Składam serdeczne podziękowania Prof. Diamantisowi Panagiotopoulosowi, dyrektorowi CMS w Heidelbergu za udostępnienie tej kolekcji dla moich badań oraz dr Marii Anastasiadou za wszechstronną pomoc przy organizacji pracy i długie dyskusje na temat gliptyki egejskiej. Podziękowania należą się także dr Oldze Krzyszkowskiej za przygotowywane przez Nią na potrzeby projektu ,Tekstylia i pieczęcie" opracowania praktyk sfragistycznych w kulturach egejskich, a także mniej formalny, lecz niezwykle ważny dla zrozumienia specyfiki kolekcji wgląd w kulisy pracy zespołu CMS w latach 60-tych i 70-tych ubiegłego wieku. 

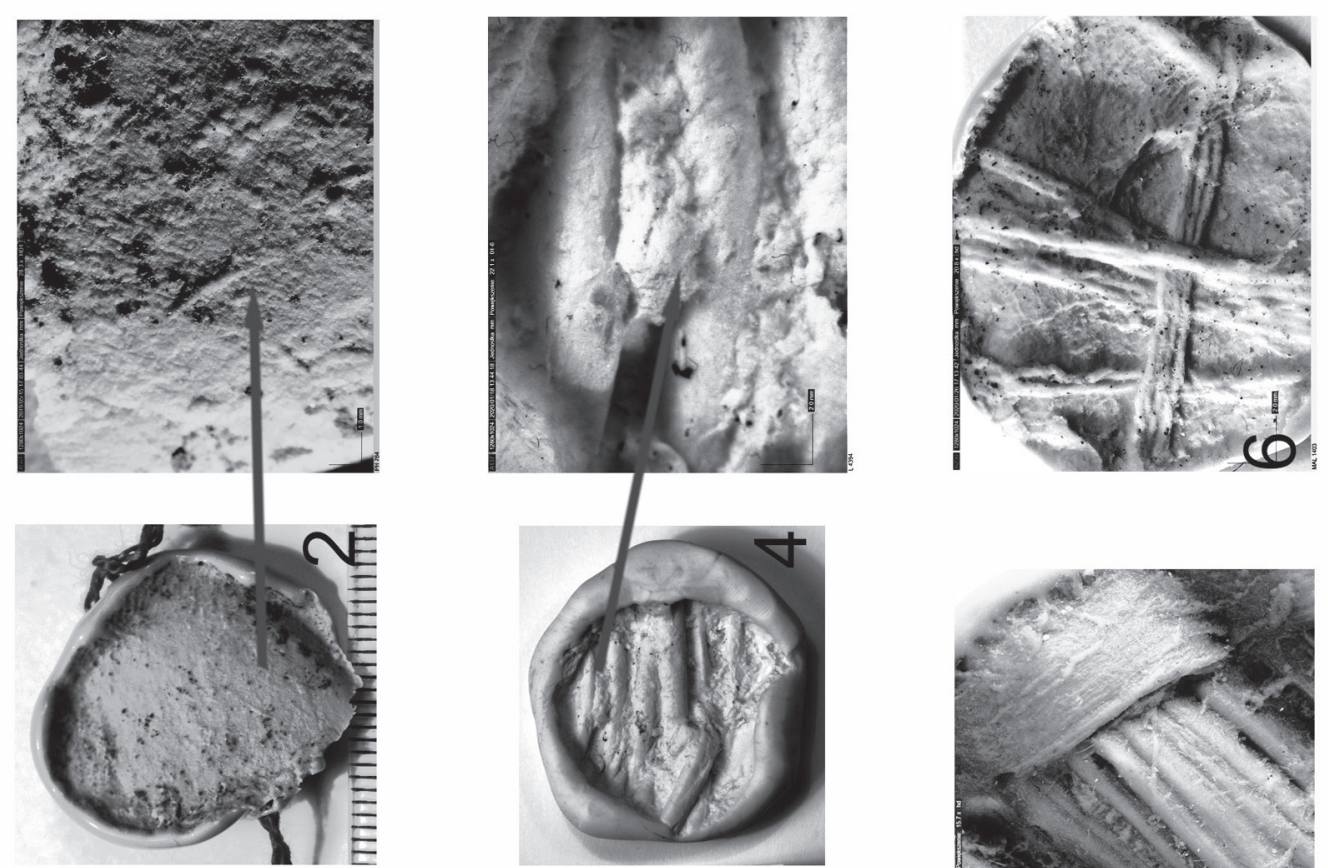

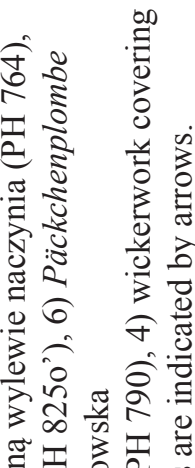

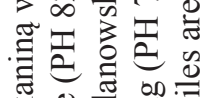

可.

ह छ

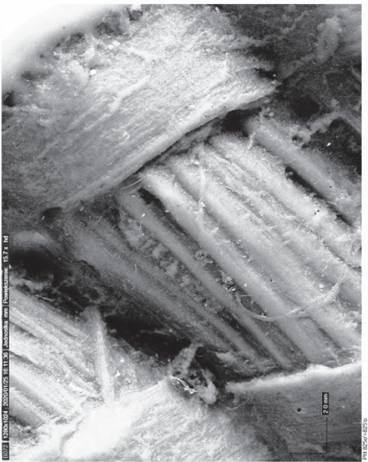

응 융

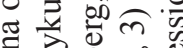

तิ

बेँ

+ $n \sum_{00}^{n}$

द्वेण ज्ञ

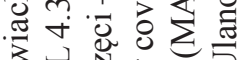

已

ำ 중

믈
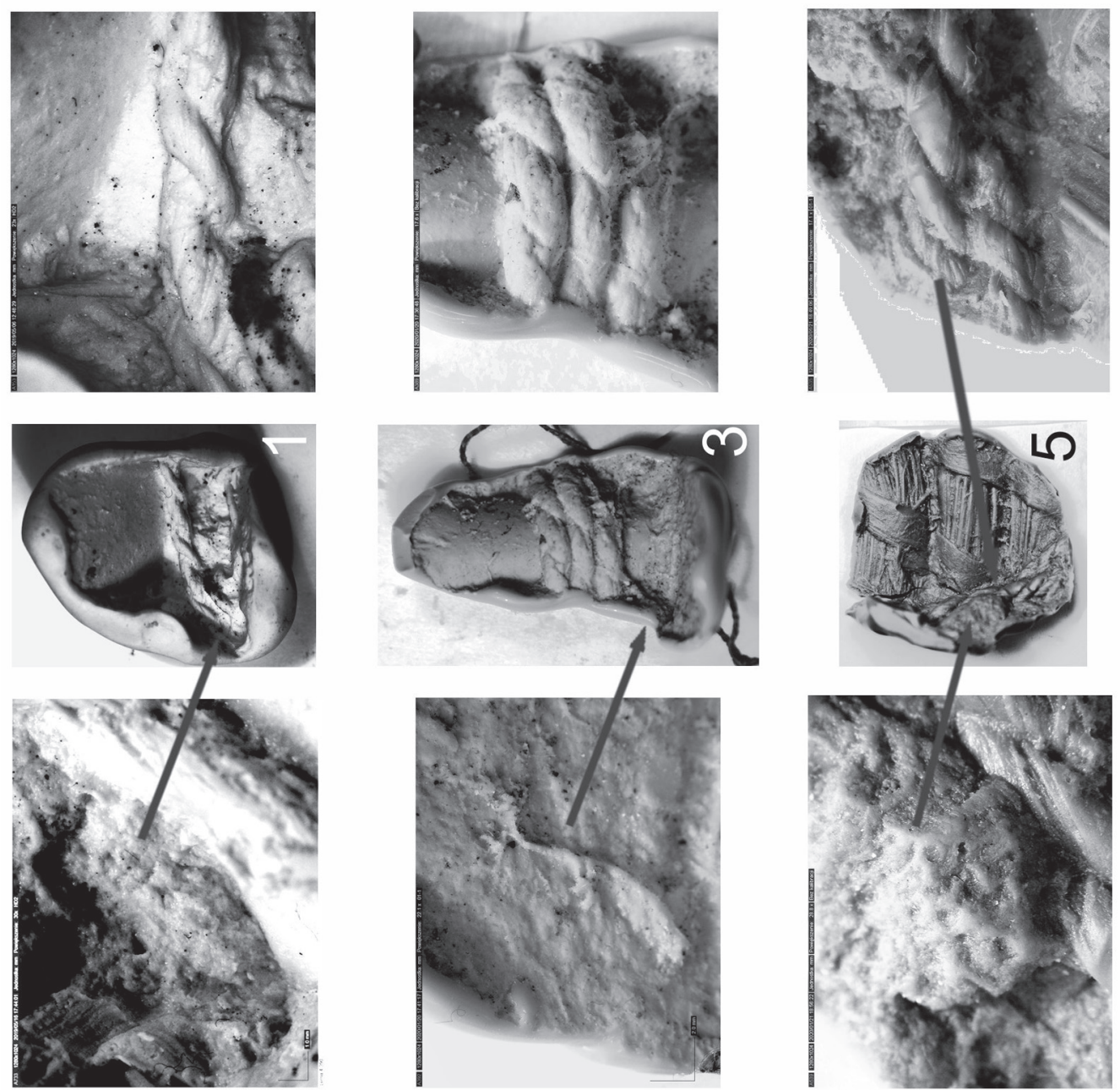

गु

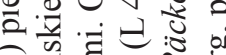

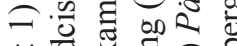

의 $6 \%$

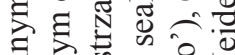

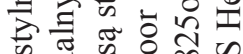

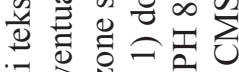

政守

矛 $\mathrm{N}$.

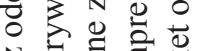

N 형 至

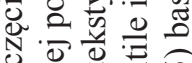

范

可高要

खे उ०

哥菏范

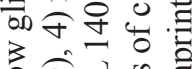

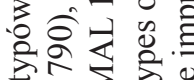

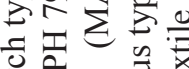

氖 焉

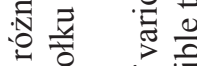

条类

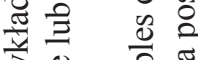

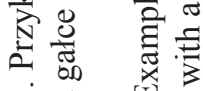

ㄷ. 피

这 - 


\section{Kilka uwag na temat terminologii}

W niniejszej pracy termin wyrób tekstylny i tekstylia oznacza, zgodnie z powszechnie przyjętą w archeologii włókiennictwa definicją, każdy wyrób z elastycznych włókien, które mogą być przędzione; a więc tekstyliami są zarówno nitki i sznurki, jak i tkaniny (cf. Michałowska 2006 dla języka polskiego). Nitki i sznurki odróżnia średnica: na potrzeby ich klasyfikacji przyjmuje się, że nitki są wyrobami o średnicy do $2 \mathrm{~mm}$, sznurki mają średnicę między 2 a $8 \mathrm{~mm}$, a liny przekraczają $8 \mathrm{~mm}$ średnicy (Rast-Eicher 2007, 305, 313; Andersson Strand 2015, 48) ${ }^{6}$. Budowę nitek i sznurków opisuje liczba i charakterystyka tworzących je elementów. Pojedyncze nitki i sznurki mogły stanowić końcowy wyrób lub być splatane ze sobą, np. po dwa lub trzy. Kierunek skrętu pojedynczej nitki - zwykle łączony z określoną tradycją włókienniczą, rzadziej z surowcem - zapisywany jest literami 's' lub 'z', które odzwierciedlają wygląd skręconych włókien, natomiast litera 'i' oznacza wyrób nieskręcony. Sznurek lub nitka skręcone $\mathrm{z}$ dwóch nitek opisywane są wg schematu: S2z, gdzie ' $S$ ' to kierunek skrętu finalnego wyrobu, ' 2 ' to informacja o liczbie pojedynczych nitek, a ' $z$ ' mówi o kierunku skrętu nitki pojedynczej (ryc. 2). Kolejnym rejestrowanym parametrem jest kąt skrętu podawany w stopniach, który odzwierciedla liczbę obrotów wrzeciona w czasie przędzenia: im mocniej skręcona nitka, a co za tym idzie bardziej wytrzymała, tym wyższy jest jej kąt skrętu. W przypadku tkanin podawana jest także ich gęstość określana przez liczbę nitek wątku i osnowy, $\mathrm{z}$ reguły nierozpoznawalnych na odciskach i określanych neutralnym określeniem system 1 i system 2 , na $\mathrm{cm}^{2}$ tkaniny $(\mathrm{n} / \mathrm{cm})$.

Słowo odcisk używane jest w niniejszej pracy w dwóch znaczeniach: stanowi określenie wyrobu włókienniczego odciśniętego w glinie oraz jego nowożytnego odcisku/odlewu w plastelinie lub silikonie

6 Przyjęta klasyfikacja nitek, sznurków i lin jest umowna i nie odzwierciedla zastosowania, ani budowy tych wyrobów. Termin nitki w odniesieniu do odcisków na spodach pieczęci obejmuje zatem zarówno przędzę, jak i cienkie i grubsze sznureczki stosowane do obwiązywania oraz pojedyncze pasma luźno skręconych, cienkich włókien, jakie owijały zwitki skóry lub pergaminu, czyli tzw. Päckchenplomben. Wyroby klasyfikowane jako liny nie zostały, jak dotąd, zidentyfikowane na odciskach. Dziękuję anonimowemu recenzentowi za zwrócenie uwagi na to, że przyjęta na potrzeby projektu klasyfikacja ma charakter formalny, a nie funkcjonalny.

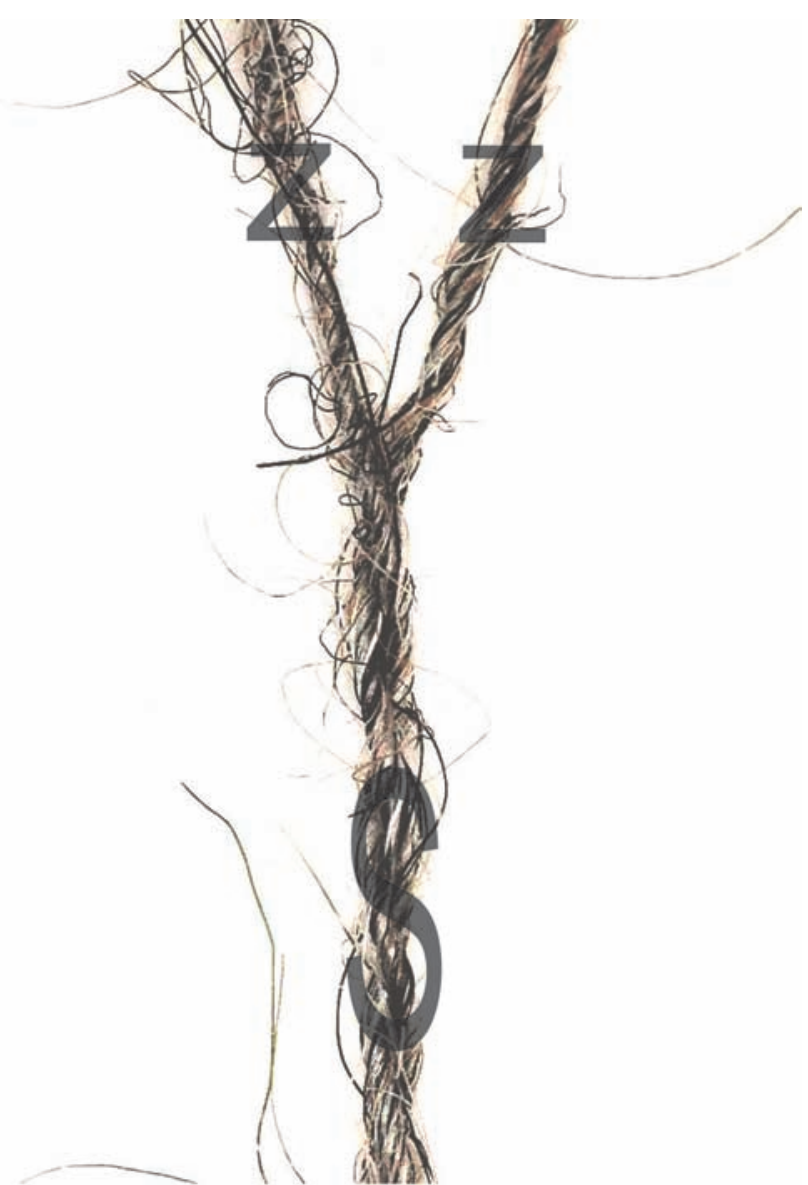

Ryc. 2. Budowa nitki lub sznurka: ręcznie przędziona nitka S2z z wełny owcy gotlandzkiej. Fot. A. Ulanowska

Fig. 2. Thread or cord structure: hand-spun S2z thread made of wool from Gotland sheep. Photo by A. Ulanowska

zdjętego ze spodu glinianej pieczęci. W tym ostatnim przypadku mamy do czynienia z odciskiem pozytywowym oryginalnego wyrobu. Sam odcisk w glinie nazywany jest także matrycą. Słowo pieczęć oznacza przedmiot, który służył do stemplowania oraz obiekt, który coś pieczętował, a więc określenie „gliniane pieczęcie" używane jest w tym samym znaczeniu co np. pieczęcie lakowe.

\section{Wiarygodność informacji utrwalonych w odciskach tekstyliów w glinie}

Liczba i wiarygodność informacji, jakich dostarczyć mogą odciski tekstyliów w glinie, zależą od stanu zachowania i rodzaju glinianej matrycy oraz właściwości odciśniętego wyrobu. Niezależnie od stanu zachowania, na dokładność odcisku wpływają także jakość użytej masy ceramicznej (cf. Grömer, Kern 2010, 3142) oraz stopień wilgotności gliny w momencie odciskania. Zbyt wilgotna glina oraz gruba 
domieszka w oczywisty sposób obniżają czytelność odcisków. Jednakże, nawet w przypadku bardzo czytelnych odcisków odtworzona być może jedynie część pierwotnych właściwości tekstyliów, takich jak budowa i kąt skrętu nitki czy rodzaj splotu lub innej techniki łączenia nitek $\mathrm{w}$ wyrobie. $\mathrm{Z}$ powodu odkształceń spowodowanych naciskiem gliny, a następnie jej kurczeniem się w trakcie wysychania, wszystkie wymiary zdejmowane z glinianych matryc są wyłącznie wartościami przybliżonymi. W przypadku odcisków tekstylnych ze spodów glinianych pieczęci, kolejne deformacje mogły pojawiać się przy zdejmowaniu ciągle wilgotnych pieczęci, jak np. w Fajstos na Krecie (Fiandra 1968, 386, 391). Niewielkie kurczenie się powierzchni zaobserwowano także na niektórych odlewach silikonowych ${ }^{7}$.

Chcąc lepiej zrozumieć zmiany pomiarów odciśniętych tekstyliów w stosunku do ich oryginalnych parametrów oraz zależności pomiędzy surowcem i strukturą wyrobu a czytelnością jego odcisku, przed rozpoczęciem badań w archiwum CMS przeprowadziłam eksperyment $\mathrm{z}$ odciskaniem próbek różnych wyrobów tekstylnych w glinie. Ponieważ nowożytne odciski przechowywane w CMS nie pozwalają na określenie jakości i rodzaju gliny, do eksperymentów użyłam wysokiej jakości gotowej masy ceramicznej. Dobór surowców i tekstyliów, łącznie siedmiu próbek powstałych na potrzeby eksperymentu lub wykonanych przez studentów w trakcie zajęć poświęconych archeologii włókiennictwa, jest szerszy niż ograniczony wybór technik i produktów poświadczonych w tekstyliach archeologicznych z epoki brązu w Grecji. Jednakże, dzięki temu odstępstwu od wierności wobec świadectw archeologicznych, lepiej zauważalne są relacje pomiędzy surowcem oraz strukturą wyrobu, a czytelnością odcisku. Odciski zdejmowane były w glinie jako odciski negatywowe, a następnie pozytywowe, na wzór odcisków przechowywanych w CMS, co pozwalało też zaobserwować różnice w dokładności pomiędzy obydwoma typami odcisków. Obserwacje mikroskopowe odcisków przeprowadziłam z użyciem mikroskopu cyfrowego DinoLite Edge AM4515ZT i zastosowaniem dodatkowego oświetlenia punktowego ( $\mathrm{w}$ ten sam sposób badałam też odciski z CMS), a ich wyniki podsumowane są w tabeli 1.

7 Dziękuję dr Marii Anastasiadou z CMS w Heidelbergu za przekazanie mi tej informacji.

8 Glina Dudziak.
Ogólna czytelność odcisków analizowanych w tym eksperymencie zależała przede wszystkim od twardości i gładkości włókien - wyroby z lnu odciskały się znacznie wyraźniej niż elastyczna i miękka wełna (i akryl), przy czym pojedyncze włókna wełny mogły dodatkowo zacierać obraz struktury wyrobu (por. ryc. 2, 3). Podobne obserwacje miały K. Grömer i D. Kern (2010), w odniesieniu do surowców, z których wykonywano sznurki odciśnięte na naczyniach z kultury ceramiki sznurowej. Czytelności odcisku sprzyjała także przestrzenność wyrobu w połączeniu z twardością surowca - w prezentowanej próbie najczytelniej odcisnęły się tekstylia wykonane techniką oplatania (próbka 3) i w splocie płóciennym (próbka 4), oba z grubych lnianych nitek. Pomiary średnicy nitek zdjęte $\mathrm{z}$ odcisków obu tych próbek, choć różne od oryginału, pozostawały zbliżone w odcisku negatywowym i pozytywowym (tab. 1 poz. 3 i 4; ryc. 3.1a-b; 2.a-b; 5). W przypadku próbki 3 również pomiary kąta skrętu na obu odciskach pozostały bliskie prawdziwym (tab. 1 poz. 3 ; ryc. 6). Jednakże, w większości badanych próbek różnice $\mathrm{w}$ pomiarach oryginalnych wyrobów i ich odcisków były znaczne (do 0,61 mm różnicy), przy czym występowało zarówno zmniejszenie, jak i powiększenie pomiarów (tab. 1). Pomniejszenie jest rezultatem wspomnianego już kurczenia się glinianej matrycy w trakcie wysychania oraz niewielkiej głębokości z jaką odcisnął się wyrób (cf. Grömer, Kern 2010, 3137). Powiększenie jest wynikiem rozciągnięcia tekstyliów na skutek nacisku gliny oraz ewentualnego zatarcia się krawędzi nitek w trakcie odciskania (ryc. 3.a-b; 4.a-b). Ogólnie, odciski negatywowe utrwalały więcej szczegółów, ale trudniej było z nich uzyskać przestrzenny obraz pod mikroskopem. Odciski pozytywowe są lekko spłaszczone w porównaniu z negatywowymi, ale struktura tekstyliów jest na nich bardziej czytelna.

Wśród współczesnych odcisków i odlewów z archiwum CMS w Heidelbergu, do analizy tekstyliów lepiej nadają się odlewy silikonowe. Ich zaletą jest elastyczność zapewniająca swobodną manipulację odciskiem i matowa powierzchnia ułatwiająca mikroskopowanie, ale i tu czytelność odcisku zależy od zastosowanego rodzaju silikonu. Wadą jest ziarnista struktura widoczna przy dużych powiększeniach, tendencja do odprysków na powierzchni oraz ryzyko pękania przy dłuższym przechowywaniu (ryc. 4). Odciski z plasteliny, choć bardzo wierne, mają błyszczącą powierzchnię, na której z czasem zbierają się krople tłuszczu, co utrudnia obserwację. Plastelina zachowuje swoją elastyczność, przez co wymaga szczególnej 
Tabela 1. Zestawienie podstawowych parametrów i pomiarów próbek tekstylnych oraz ich odcisków negatywowych i pozytywowych w glinie.

Table 1. Comparison of the basic parameters and measurements of selected textile samples and their negative and positive impressions on clay.

\begin{tabular}{|c|c|c|c|}
\hline $\begin{array}{l}\text { Typ wyrobu i jego } \\
\text { parametry }\end{array}$ & Próbka tekstylna & Odcisk negatywowy & Odcisk pozytywowy \\
\hline \multicolumn{4}{|c|}{ 1. Mechanicznie przedziona nitka lniana } \\
\hline Ogólna struktura nitki & zwielokrotniona & $?$ & $?$ \\
\hline Budowa i kierunek skrętu & S4i & $\mathrm{Z}$ & $?$ \\
\hline Kąt skrętu w stopniach & $22-24$ & 29 & $?$ \\
\hline Średnica $\mathrm{w}$ mm & $0,57-0,61$ & $0,54-0,69$ & 0,67 \\
\hline \multicolumn{4}{|c|}{ 2. Ręcznie przędziona nitka wetniana } \\
\hline Budowa nitki & pojedyncza & $?$ & $?$ \\
\hline Budowa i kierunek skrętu & $\mathrm{z}$ & $\mathrm{s}$ & $\mathrm{z}$ \\
\hline Kąt skrętu w stopniach & $33-46$ & $37-39$ & $33-48$ \\
\hline Średnica $\mathrm{w} \mathrm{mm}$ & $0,61-1$ & $0,66-1,18$ & $0,74-0,90$ \\
\hline \multicolumn{4}{|c|}{ 3. Wyrób z oplatanych wątkiem nitek osnowy, mechanicznie przędziony len } \\
\hline Splot & $\begin{array}{l}\text { oplatanie nitek } \\
\text { osnowy watkiem w } \\
\text { kierunku S i Z }\end{array}$ & $\begin{array}{l}\text { oplatanie nitek } \\
\text { osnowy wątkiem } \\
\text { w kierunku S i Z }\end{array}$ & $\begin{array}{l}\text { oplatanie nitek } \\
\text { osnowy wątkiem } \\
\text { w kierunku S i Z }\end{array}$ \\
\hline $\mathrm{N} / \mathrm{cm}$ & $4 \times 5$ & $4 \times 5$ & $4 \times 5$ \\
\hline Ogólna struktura nitki & zwielokrotniona & zwielokrotniona & $?$ \\
\hline Budowa i kierunek skrętu & $\mathrm{S} 4 \mathrm{z}$ & $\mathrm{Z}$ & $\mathrm{s}$ \\
\hline Kąt skrętu w stopniach & $33-46$ & $33-36$ & 34 \\
\hline Średnica $\mathrm{w}$ mm & $1-1,37$ & $0,86-1,3$ & $0,88-1,34$ \\
\hline \multicolumn{4}{|c|}{ 4. Splot plócienny kryty wątowo, mechanicznie przędziony len } \\
\hline Splot & $\begin{array}{l}\text { płócienny kryty } \\
\text { wątkowo }\end{array}$ & $\begin{array}{l}\text { płócienny kryty } \\
\text { wątkowo lub } \\
\text { osnowowo }\end{array}$ & $\begin{array}{l}\text { płócienny kryty } \\
\text { wątkowo lub } \\
\text { osnowowo }\end{array}$ \\
\hline $\mathrm{N} / \mathrm{cm}$ & $2-4 \times 12$ & $3 \times 9$ & $4 \times 8$ \\
\hline Ogólna struktura nitki & zwielokrotniona & zwielokrotniona & $?$ \\
\hline Budowa i kierunek skrętu & S3i & $\mathrm{Z}$ & $?$ \\
\hline Kąt skrętu w stopniach & $30-38$ & $26-48$ & $?$ \\
\hline Średnica w mm & $1,07-1,12$ & $1,27-1,49$ & $1,27-1,51$ \\
\hline \multicolumn{4}{|c|}{ 5. Krajka tabliczkowa, nitki akrylowe } \\
\hline Splot & $\begin{array}{l}\text { skręt 's' i 'z' z jedną } \\
\text { osią symetrii }\end{array}$ & $?$ & skręt z osią symetrii? \\
\hline $\mathrm{N} / \mathrm{cm}$ & $20 \times 2$ & $?$ & $?$ \\
\hline Ogólna struktura nitki & zwielokrotniona & $?$ & $?$ \\
\hline Budowa i kierunek skrętu & $\mathrm{S} 2 \mathrm{z}$ & $?$ & $\mathrm{~s}$ \\
\hline Kąt skrętu w stopniach & $30-40$ & $?$ & $24-45$ \\
\hline Średnica w mm & $1,46-1,67$ & $1,55-1,87$ & $1,27-1,83$ \\
\hline \multicolumn{4}{|c|}{ 6. Krajka w splocie plóciennym, nitki welniane i akrylowe } \\
\hline Splot & płócienny & płócienny? & płócienny? \\
\hline $\mathrm{N} / \mathrm{cm}$ & $7 \times 2$ & $6 \times 3$ & $6 \times 5$ \\
\hline
\end{tabular}




\begin{tabular}{|l|l|l|l|}
\hline Ogólna struktura nitki & zwielokrotniona & $?$ & $?$ \\
\hline Budowa i kierunek skrętu & S2z & $?$ & $?$ \\
\hline Kąt skrętu w stopniach & $23-40$ & $?$ & $?$ \\
\hline Średnica w mm & $1,43-2,28$ & $1,82-2,54$ & $1,47-2,14$ \\
\hline 7. Krajka wykonana w technice sprangu, nitki akrylowe & s & siatka? \\
\hline Splot & $\begin{array}{l}\text { splatanie } \\
\text { i przeplatanie }\end{array}$ & $?$ & 6 \\
\hline N/cm & 4 & 6 & zwielokrotniona \\
\hline Ogólna struktura nitki & zwielokrotniona & $?$ & S \\
\hline Budowa i kierunek skrętu & S3z & $?$ & 39 \\
\hline Kąt skrętu w stopniach & $33-43$ & $?$ & $1,65-2,53$ \\
\hline Średnica w mm & $1,86-1,92$ & $1,49-1,59$ & \\
\hline
\end{tabular}

uwagi przy manipulowaniu, ponadto, ponieważ jest kleista, zbierają się na niej zabrudzenia niemożliwe do usunięcia bez ryzyka uszkodzenia odcisku (ryc. 4).

\section{Rozpoznawanie surowców}

Odciski tekstyliów uważane są również za potencjalne źródło informacji o surowcach włókienniczych. Jak się wydaje, przy czytelnym odcisku możliwe jest odróżnienie włókien pochodzenia roślinnego i wełny, ale już rozpoznanie konkretnego surowca, np. lnu, łyka, ale także np. włosia końskiego lub ścięgien staje się problematyczne, tym bardziej, że wybór dostępnych surowców musiał być bardzo szeroki ${ }^{9}$. Dodatkowo, o wyglądzie włókien decydowała technika ich obróbki - włókna tego samego rodzaju mogły mieć odmienny wygląd w zależności od ich doboru, techniki pozyskiwania oraz przetwarzania w nitki. Podobne wnioski zdają się wynikać z cytowanego już artykułu K. Grömer i D. Kern (2010), gdzie nawet przy obserwacji próbek z odciskami różnych surowców z zastosowaniem mikroskopu skaningowego, bezbłędne rozpoznanie surowca bez uprzedniej wiedzy o tym co dokładnie zostało odciśnięte, wydaje się niemożliwe.

W odniesieniu do odcisków tekstylnych na spodach glinianych pieczęci z epoki brązu w Grecji i Anatolii, istnieje szereg interpretacji identyfikujących surowce, które oparte są na ogólnym podobień-

9 Za dostarczenie próbek wyrobów lub włókien pałki szerokolistnej, łyka lipowego, końskiego włosia, jelit świni i 10-cio miesięcznego barana, ścięgien jelenia oraz garbowanego rzemyka ze skóry wołowej dziękuję Muzeum Archeologicznemu w Biskupinie oraz dr Magdalenie Przymorskiej-Sztuczka. stwie cech widocznych na odcisku z właściwościami określonego surowca, uzasadnionym czasami dodatkową argumentacją. Na przykład, R. Laurito w swojej analizie licznego zbioru odcisków sznurków i lin ze stanowiska Arslantepe w Anatolii zauważa, że grubsze i niezbyt gładkie włókna mogły być konopne, natomiast przypominające włosy włókna delikatne i gładkie mogły być lniane lub pochodzić z runa kozy lub owcy. Przy czym, jej zdaniem, kierunek skrętu S, odpowiadający naturalnemu skrętowi włókien lnu, może wskazywać na ten ostatni surowiec, podczas, gdy kierunek Z sugeruje wełnę (2007b, 383-384). Odciski sznurków o gładkiej powierzchni ${ }^{10}$, uważane są przez nią za ozdobne, zapewne wełniane plecionki, przypominające współczesne sznury do zasłon (2007b, 384). W Arslantepe, ze względu na jakość masy ceramicznej, trudne do rozróżnienia są wąskie tasiemki z tkaniny od rzemyków - obu wyrobów używano zapewne do wiązania worków oraz zabezpieczenia drzwi (Laurito 2007b, 388). W odciskach wyrobów organicznych z Kültepe w Anatolii rozpoznane są trzciny, pióra i liście oraz, w sznurkach, długie włókna z roślin włóknistych, takich jak len, i krótkie, nieregularne włókna przypominające wełnę (Andersson Strand et al. 2017, 90-91).

Próby identyfikacji surowców w materiale z Grecji epoki brązu podejmowali, jak dotąd, przede wszystkim specjaliści od gliptyki. W jednym z odcisków z Fajstos na Krecie (PH 825o’, ryc. 1.5), E. Fiandra rozpoznała matę z sitowia oraz liści palmy (1968,

10 Podobne sznurki odciśnięte na spodach pieczęci z Grecji epoki brązu są interpretowane przeze mnie, zgodnie z wcześniejszym rozpoznaniem W. Müllera i I. Pini (1997, 67-69), jako rzemyki o różnych przekrojach. 

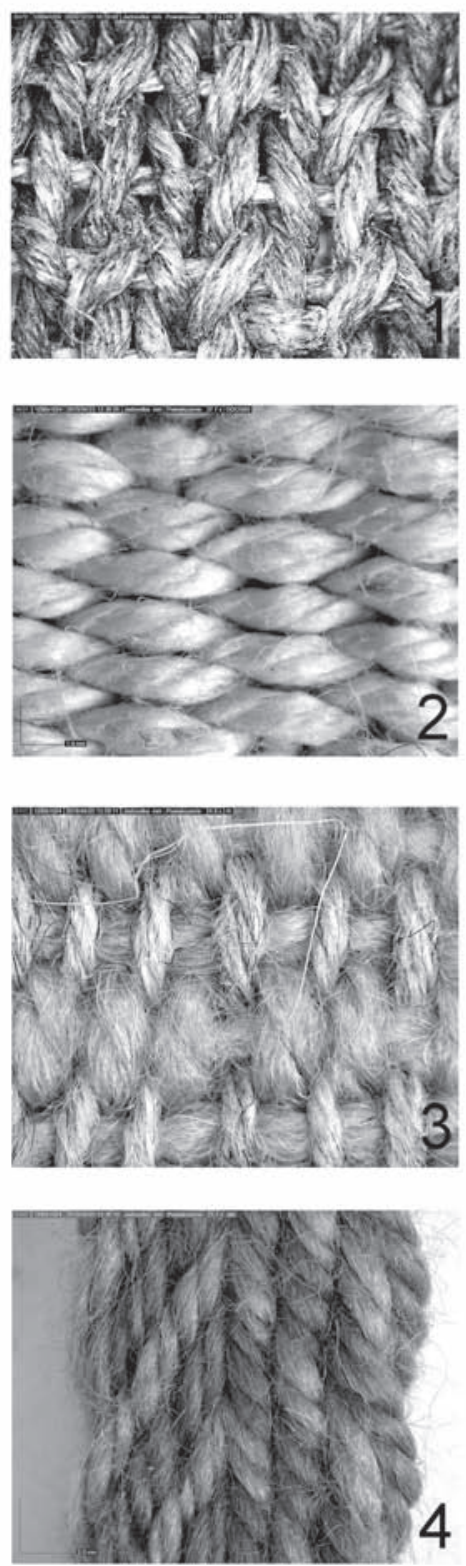
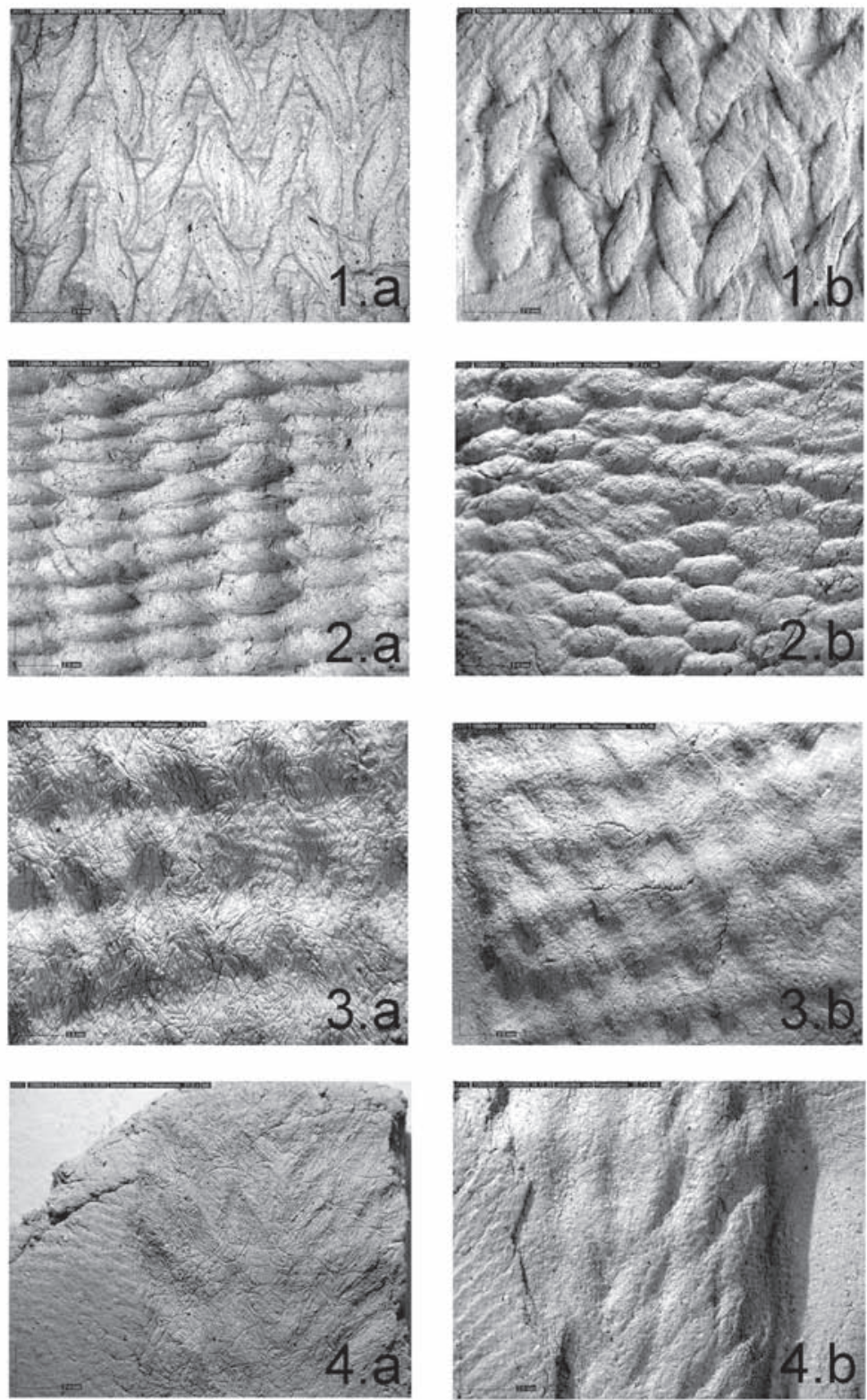

Ryc. 3. Próbki wyrobów tekstylnych w porównaniu do ich odcisków negatywowych (a) i pozytywowych (b): 1) technika oplatania nitek osnowy wątkiem, mechanicznie przędziony len, 2) splot płócienny kryty wątkowo, mechanicznie przędziony len, 3) krajka w splocie płóciennym z nitek wełnianych i akrylowych,

4) krajka tabliczkowa $z$ nitek akrylowych. Fot. A. Ulanowska

Fig. 3 Samples of actual textiles as compared to their positive (a) and negative (b) impressions on clay:

1) Twined linen textile, 2) Weft-faced linen tabby, 3) Woolen and acrylic tabby band, 4) Acrylic tablet-woven band. Photo by A. Ulanowska

$389)^{11}$. W niezwykle solidnym opracowaniu odcisków ze spodów glinianych pieczęci z Pylos w Messenii,

11 Analiza tego odcisku pod mikroskopem cyfrowym nie pozwala na jednoznaczne rozpoznanie surowca, ale umożliwia rozpoznanie techniki produkcji odciśniętej ,maty" jako tzw. coiled basketry. Na powierzchni przylegającej prostopadle do maty/koszyka znajdują się odciśnięte wraz z odniesieniami do Knossos na Krecie, W. Müller i I. Pini zaproponowali szerokie spektrum potencjalnych surowców w oparciu analizę mikroskopową szeregu eksperymentalnych odcisków sznurków i rzemyków ze skóry, pergaminu, jelita owczego, ścięgien

fragmenty tkaniny i sznurka, niezauważone przez Fiandrę w oglądzie makroskopowym. 

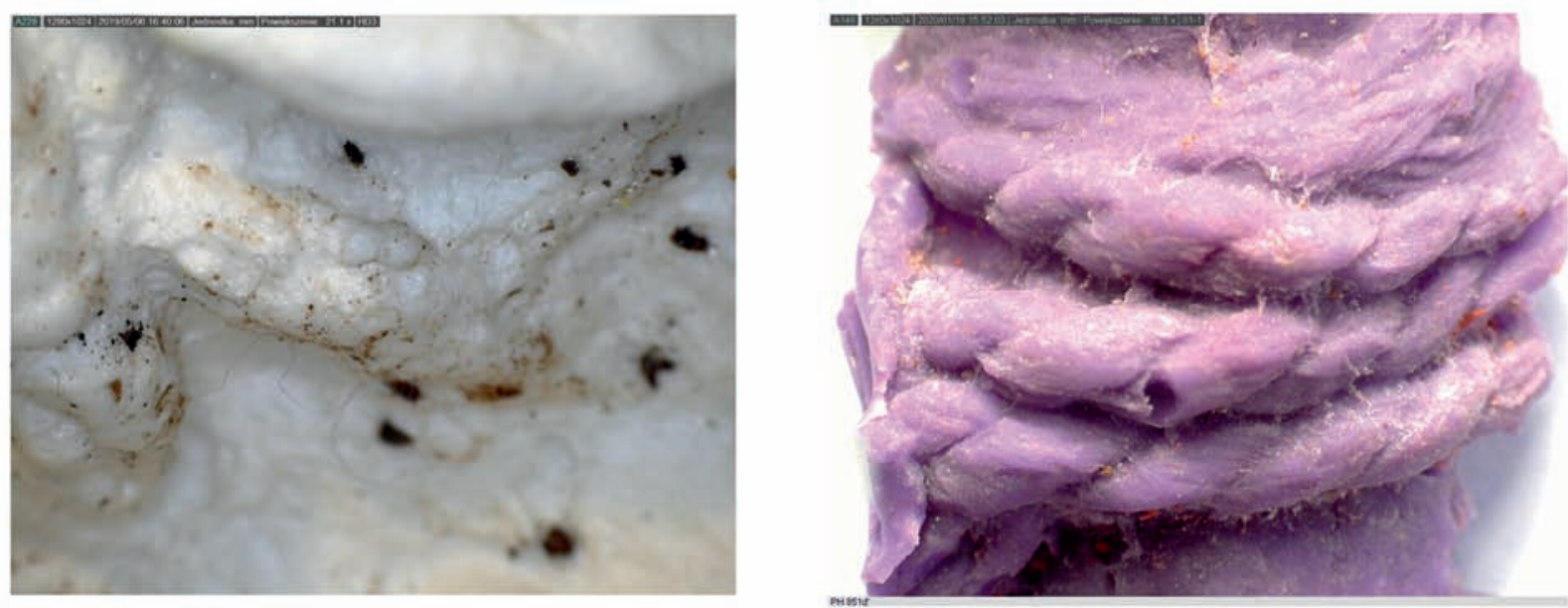

Ryc. 4. Kolorowe zdjęcia Dino-Lite odcisku w plastelinie (L 4.373) i odlewu silikonowego (PH 851d'). Odciski - CMS Heidelberg, fot. A. Ulanowska

Fig. 4. Colour Dino-Lite photos of plasticine (L 4.373) and silicone (PH 851d') casts. Casts - CMS Heidelberg, photo by A. Ulanowska

nieokreślonego zwierzęcia, łyka, konopi i sitowia (1997, cf. Müller 1999). W odniesieniu do unikatowego odcisku tkaniny na spodzie glinianej pieczęci z Geraki w Lakonii, analizowanego przez G. Vogelsang-Eastwood, archeolożkę i specjalistkę w zakresie włókiennictwa egipskiego, sugerowane są włókna pochodzenia roślinnego, takie jak poświadczone w tym czasie w basenie Morza Śródziemnego len, ramia lub pokrzywa $(1999,374)^{12}$.

Przeprowadzona przeze mnie analiza mikroskopowa odcisków na spodach glinianych pieczęci $\mathrm{z}$ archiwum CMS potwierdza użycie w praktykach pieczętowania w Egei rozmaitych surowców pochodzenia roślinnego i zwierzęcego, w tym skórzanych rzemieni i, być może, pergaminu, jelit i ścięgien, ale, jak dotychczas, bez wełny. Według moich obserwacji, próba identyfikacji konkretnego surowca, tj. gatunku łyka czy rośliny o włóknistych łodygach, a nawet rozróżnienie nitki ze ścięgien i nitki z delikatnych włókien pochodzenia roślinnego, wydaje się być niemożliwe (ryc. 5). Możliwe jest jednak wyodrębnienie szeregu cech charakteryzujących poszczególne kategorie surowców, takich jak np. łyko, łodygi roślin włóknistych, wiklina, włosie końskie, ścięgna, jelita i rzemyki, które opisują ich mikrostrukturę, powierzchnię,

12 W tekstyliach archeologicznych z Grecji epoki brązu potwierdzone są takie surowce pochodzenia roślinnego, jak len i pokrzywa (Spantidaki, Moulherat 2012) oraz igły sosnowe w tzw. ,słomiance” z Fajstos (Margariti et al. 2012). łamliwość i charakterystyczne uszkodzenia, przekrój, czy wygląd zakończenia (tab. 2). Zestawienie powstałe dzięki analizie mikroskopowej próbek surowców współcześnie dostępnych, sugeruje, że jednoczesne występowanie kilku cech może zwiększać prawdopodobieństwo identyfikacji surowca. Na przykład, odciski z Lerna (L 4.4297'13), Fajstos (PH 721) i Knossos (KN 997) - wydają się utrwalać wyroby z łyka lub lekko skręconej łodygi, podobnej np. do pałki szerokolistnej, a niewielka seria odcisków z Fajstos, Knossos, Malia i Chania (ryc. 5) - rzemyki. Jednakże, pamiętać należy, że wiele z cech wymienionych w tabeli 2 jest wspólnych dla różnych surowców albo, jak zakończenia, rzadko uchwytnych w odciskach. Dla większości odcisków z archiwum CMS możliwe jest zatem tylko bardzo ogólne rozpoznanie włóknistej struktury, wskazującej raczej na surowce pochodzenia roślinnego. Ścięgna i jelita zostały zasugerowane

13 Podawane w niniejszej pracy numery referencyjne odnoszą się do numerów pod jakimi nowożytne odciski ze spodów glinianych pieczęci zostały zarejestrowane w archiwum CMS. W przypadku Lerna numery glinianych spodów pieczęci i ich plastelinowych odcisków są tożsame. Często jednak oznaczenie CMS wskazuje na stanowisko, chociaż nr inwentarza jest zgodny z nr. muzealnym. Np. odcisk nr KN 997 został zdjęty ze spodu glinianej pieczęci o nr inw. HMs 997 przechowywanej w Muzeum Archeologicznym w Iraklionie. Ze względu na to, że nowożytne odciski z CMS i ich gliniane pierwowzory są różnymi obiektami, odrębność numerów zostaje zachowana wszędzie tam, gdzie występuje w Archiwum CMS. 


\begin{tabular}{|c|c|c|c|c|c|}
\hline 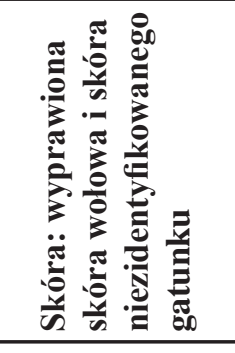 & 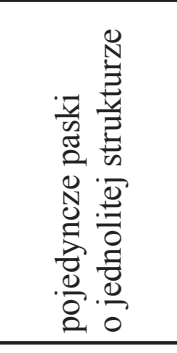 & 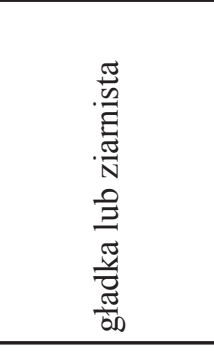 & 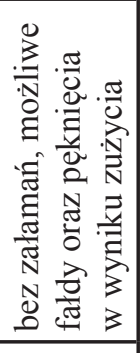 & 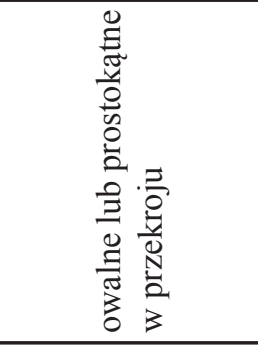 & 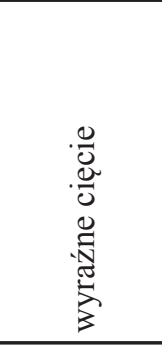 \\
\hline 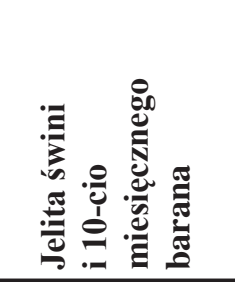 & 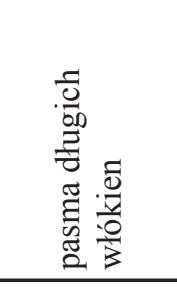 & $\begin{array}{l}\frac{\pi}{\tilde{y}} \\
\frac{\pi}{60} \\
\end{array}$ & 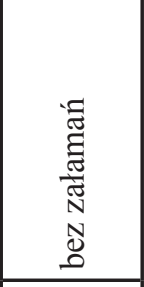 & 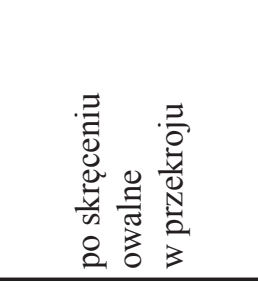 & 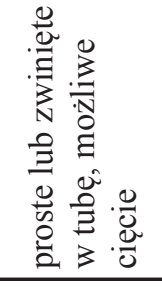 \\
\hline 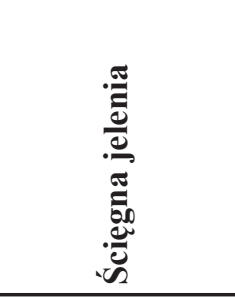 & 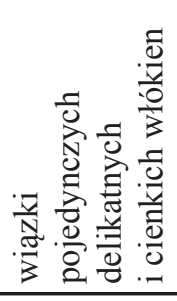 & 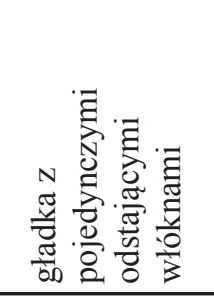 & 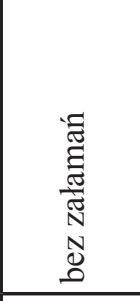 & 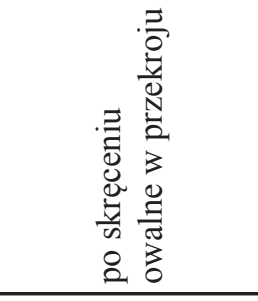 & 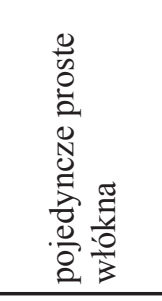 \\
\hline 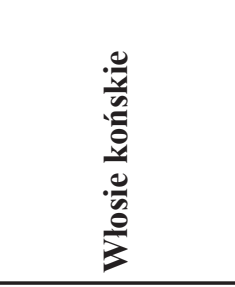 & 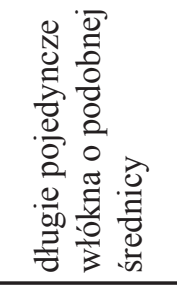 & $\begin{array}{l}\frac{\pi}{\tilde{y}} \\
\frac{\pi}{b 0} \\
0\end{array}$ & 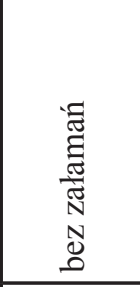 & $\begin{array}{l}\frac{\lambda}{80} \\
\frac{\pi}{0} \\
\text { 흥 }\end{array}$ & 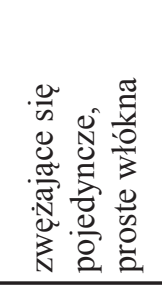 \\
\hline 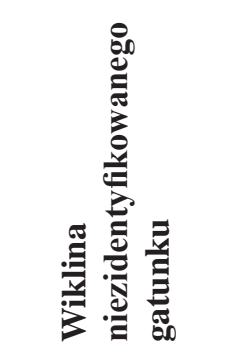 & 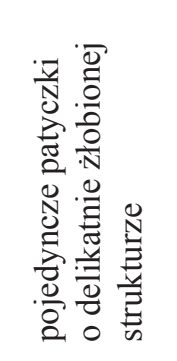 & $\frac{\frac{\pi}{\tilde{y}}}{\frac{\pi}{60}}$ & 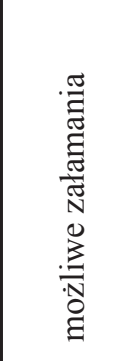 & 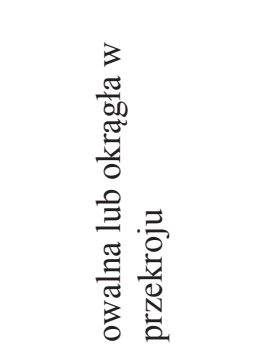 & 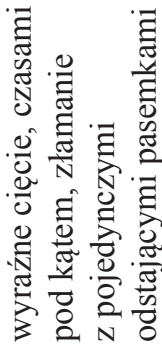 \\
\hline 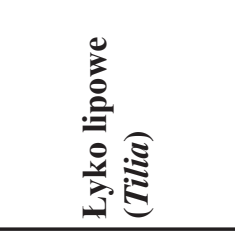 & 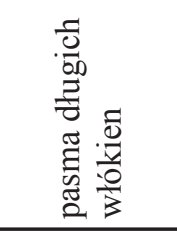 & 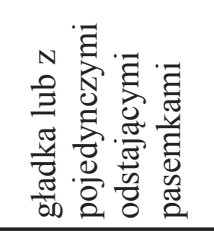 & 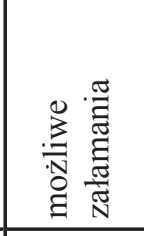 & 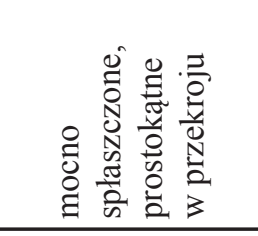 & 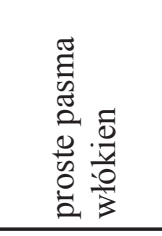 \\
\hline 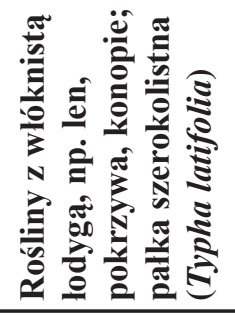 & 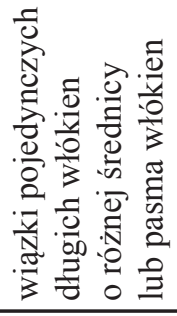 & 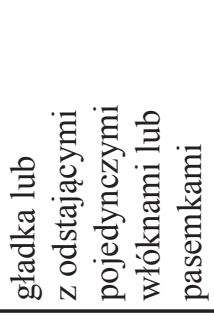 & 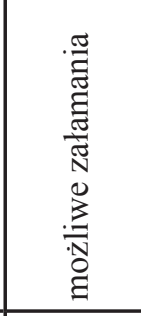 & 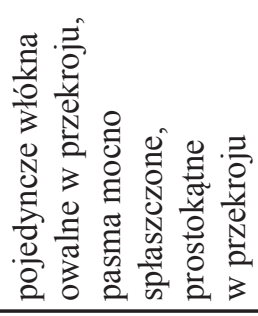 & 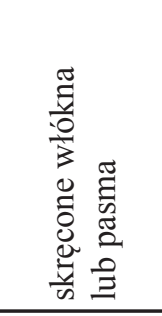 \\
\hline 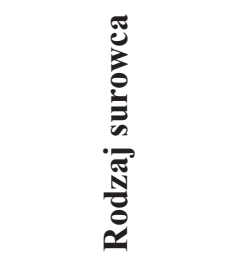 & 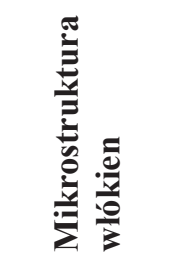 & 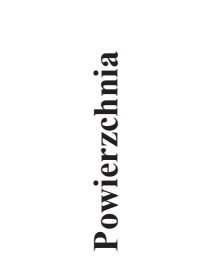 & 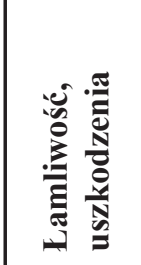 & 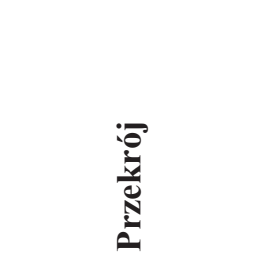 & 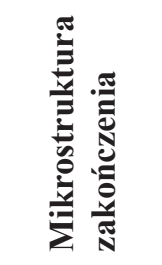 \\
\hline
\end{tabular}




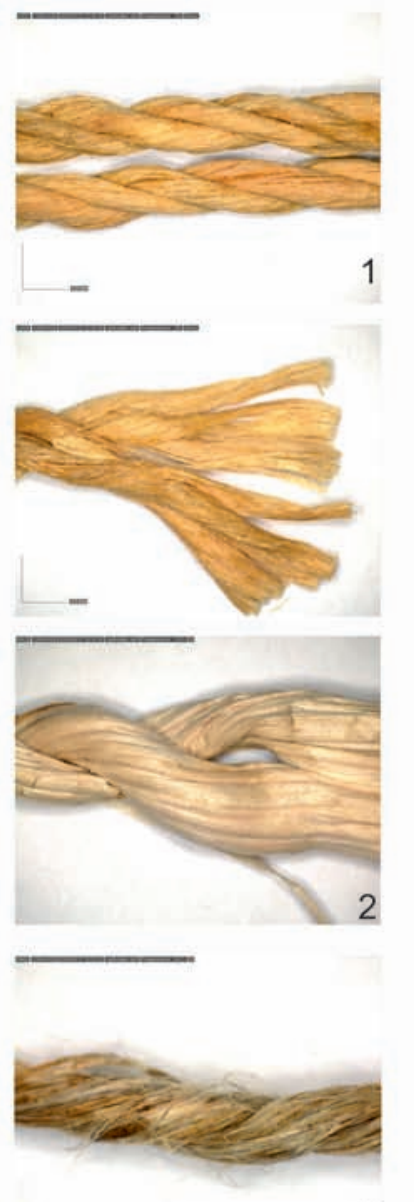

3

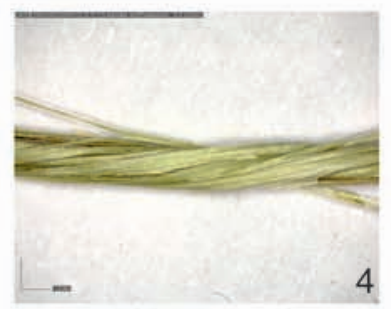

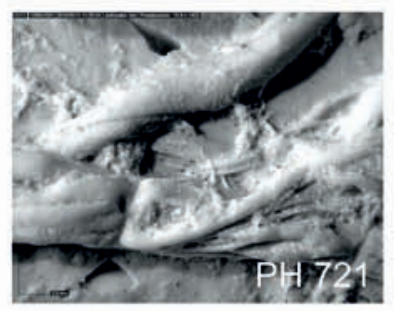

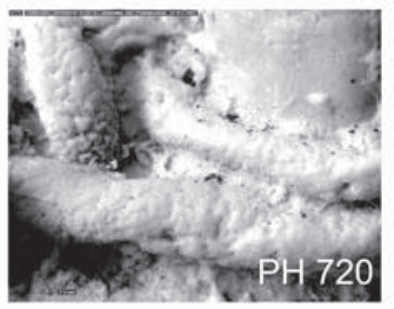

6
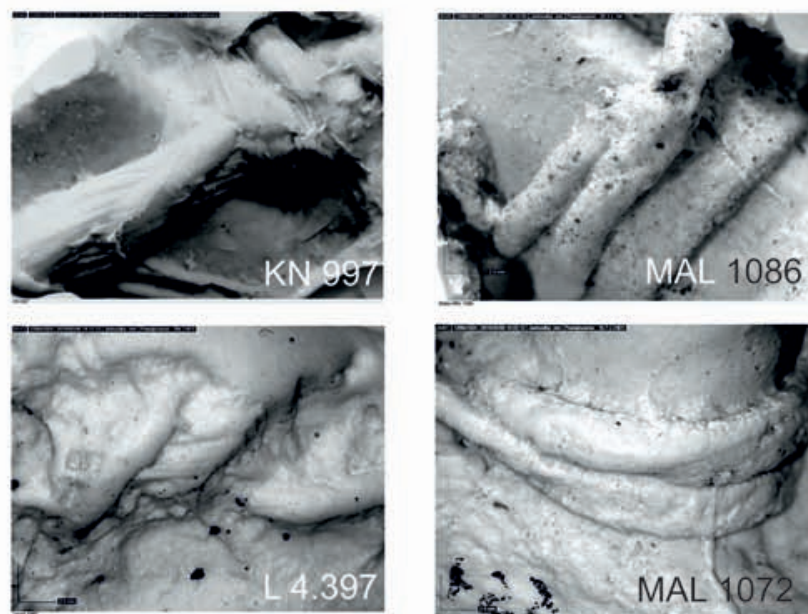

7

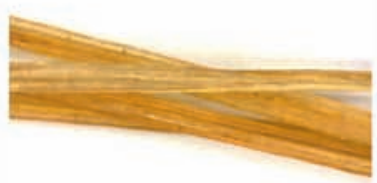

8
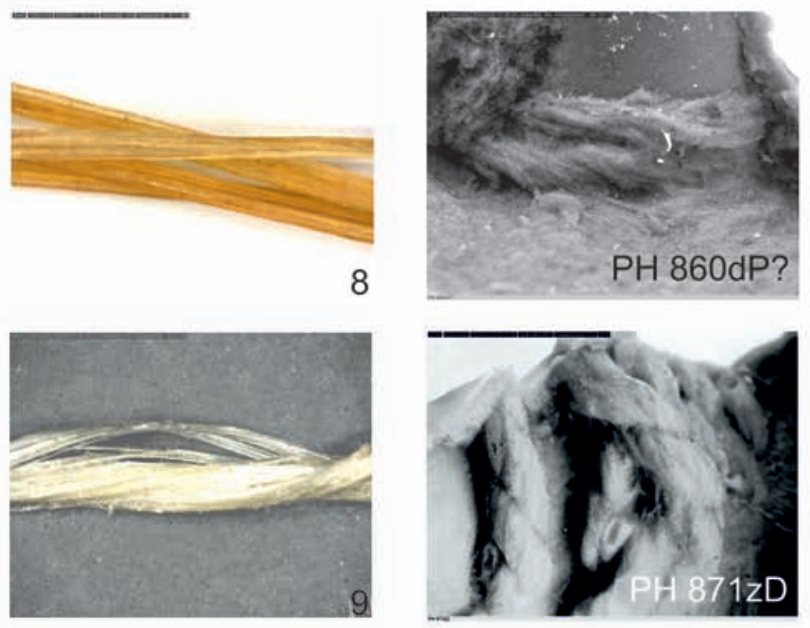
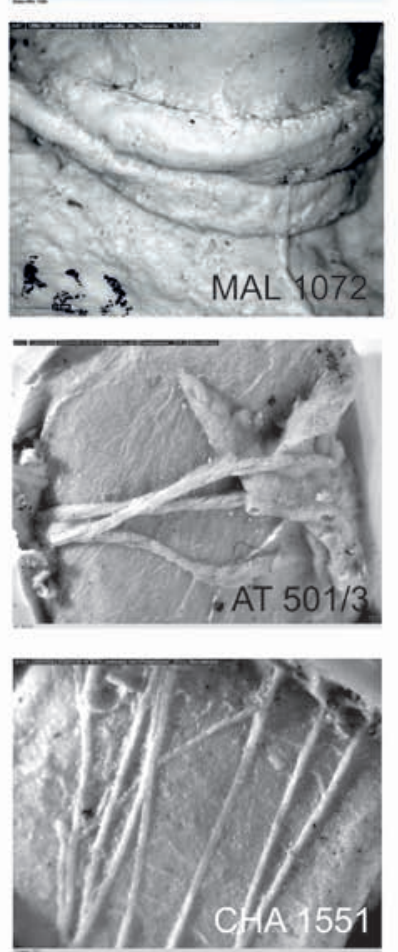

Ryc. 5. Wybór włókien/wyrobów pochodzenia roślinnego i zwierzęcego w zestawieniu z odciskami z CMS Heidelberg

1) łyko z lipy, 2) pałka szerokolistna, 3) len po moczeniu, 4) pokrzywa, 5) rzemyk z niezidentyfikowanej skóry,

6) rzemyk z garbowanej skóry wołowej, 7) jelito świni, 8) jelito młodego barana, 10) ścięgna jelenia.

$$
\text { Odciski - CMS Heidelberg, fot. A. Ulanowska }
$$

Fig 5. A choice of plant and animal-origin fibres/products, as compared to the CMS Heidelberg casts: 1) lime bast,

2) bulrush, 3) retted flax, 4) nettle, 5) thong of unidentified animal skin, 6) thong of tanned bovine skin, 7) pig gut,

8) young ram gut, 9) sinews of deer. Casts - CMS Heidelberg, photo by A. Ulanowska

przez W. Müllera jako surowce używane, m.in., do obwiązywania złożonych pakietów pergaminu zwanych w studiach gliptycznych Päckchenplomben, gdzie odciski często utrwalają cienkie nitki bez widocznego skrętu (por. ryc. 5) oraz, razem z rzemykami, do mocowania pieczęci w formie glinianych bryłek zawieszonych na sznurku (Müller 1997; Müller, Pini 1999; Krzyszkowska 2019; 2020). Te dwie grupy odcisków ciągle czekają na systematyczną, kompleksową analizę, ale uważny ogląd mikroskopowy kilku przykładów sugeruje, że jednoznaczne rozróżnienie pomiędzy nieskręconymi jelitami, ścięgnami i długimi włóknami roślinnymi jest przy cienkich nitkach niemożliwe lub problematyczne. 


\section{KOLEKCJA ODCISKÓW TEKSTYLNYCH W ARCHIWUM CMS W HEIDELBERGU}

Idea CMS - korpusu zbierającego wszystkie pieczęcie i ich odciski pochodzące z Grecji epoki brązu w dokładnym i spójnym opracowaniu - narodziła się w 1958 r. Od tego czasu opracowano i wydano 13 tomów CMS publikujących pieczęcie, niektóre wraz z suplementami, oraz 10 Beihefte: tomów z opracowaniami tematycznymi ${ }^{14}$. W archiwum CMS zgromadzone są wszystkie nowożytne odciski, jakie zostały zdjęte na potrzeby tego monumentalnego zamierzenia, w tym wybór odcisków ze spodów pieczęci, z których tylko niewielka część została opublikowana w rozdziałach traktujących o typologii glinianych pieczęci (np. Müller 1997; 1999; 2002; Müller, Pini 1997; Krzyszkowska 2005). Znaczna część danych z tomów publikujących pieczęcie, niezależnie od akcji stopniowego digitalizowania wszystkich druków CMS, znajduje się w wolnym dostępie w CMS Arachne - bazie danych online ${ }^{15}$.

W ramach projektu "Tekstylia i pieczęcie", w czasie dwóch pobytów studyjnych w CMS w 2019 i 2020 r., przebadanych zostało 227 odcisków spodów pieczęci utrwalających szeroko rozumiane tekstylia oraz odciski rzemieni (4 przykłady), koszyków lub mat (12 przykładów, łącznie z niepewnymi identyfikacjami). W trakcie badań okazało się, że pierwotnie przyjęte szacunki dotyczące liczby odcisków tekstyliów są zaniżone ${ }^{16}$. Obecnie ostrożnie oceniam, że w archiwum CMS znajduje się ok. 1600 kolejnych odcisków tekstylnych na spodach pieczęci oraz bliżej nieokreślona liczba odcisków tekstylnych na wierzchnich stronach, czyli tych, na których stawiano pieczęcie. Tak znaczna liczba odcisków wymaga badań dłuższych niż czas realizacji projektu „Tekstylia i pieczęcie" i planowana jest ich kontynuacja po zakoń-

14 Pełna lista opublikowanych tomów (CMS I-XIII i CMS Beihefte 1-10) dostępna jest na stronie www archiwum CMS w Heidelbergu: https://www.uni-heidelberg.de/ fakultaeten/philosophie/zaw/cms/cmsseries/theseries.html, dostęp 15.12.2020 r. Liczba egejskich pieczęci i odcisków znajdujących się w archiwum CMS przekracza obecnie 12000 , choć nie wszystkie $\mathrm{z}$ nich zostały opublikowane (cf. Krzyszkowska 2005, 1).

15 https://arachne.uni-koeln.de/drupal/?q=en/node/ 196, dostęp 15.12.2020 r.

16 Szacunki te opierały się na publikacjach oraz bardzo ogólnych wielkościach sugerowanych w rozmowach z dr O. Krzyszkowską i prof. D. Panagiotopoulosem. czeniu projektu. Dla uzyskania optymalnych wyników cząstkowej analizy odcisków tekstylnych z CMS w Heidelbergu, zdecydowałam się w pierwszej kolejności przebadać w sposób pełny wszystkie odciski ze stanowisk Lerna (53 odciski) oraz Fajstos na Krecie (145 odcisków) ${ }^{17}$. Pomimo że Fajstos i Lerna oddziela ok. 750 lat i $500 \mathrm{~km}$, praktyki pieczętowania w obu ośrodkach były podobne i obejmowały bezpośrednie stemplowanie takich obiektów, jak wspomniane już skrzydła drzwi, gałki od drzwi i drzwiczek od skrzynek, brzegi naczyń, koszyków itp. (ryc. 1). Wybór tych dwóch stanowisk pozwala zatem na porównanie cech wyrobów tekstylnych używanych w podobnych praktykach stemplowania we wczesnym i środkowym okresie epoki brązu w Grecji lądowej i na Krecie.

\section{Baza danych ,Textiles and seals" jako nowe narzędzie online}

Chociaż częściowa informacja o szeregu źródeł badanych przez projekt „Tekstylia i pieczęcie”, takich jak ikonografia produkcji włókienniczej, czy stemplowane narzędzia włókiennicze, jest dostępna w bazie CMS Arachne, zarówno sposób publikowania indywidualnych rekordów, jak i słowniki wyszukiwarek CMS Arachne tylko w ograniczonym stopniu odpowiadają pytaniom badawczym stawianym przez projekt. Specjalnie na potrzeby projektu „Tekstylia i pieczęcie” zaprojektowana została zatem online nowa baza danych, która składa się z trzech modułów poświęconych, odpowiednio, ikonografii produkcji włókienniczej, stemplowanym narzędziom włókienniczym oraz odciskom tekstylnym na spodach glinianych pieczęci. Baza utworzona została przez Centrum Kompetencji Cyfrowych UW, partnera technicznego projektu, jako baza relacyjna zbudowana w PostgreSQL z wyszukiwarkami dla modułów opartymi na Bootstrap,

17 Przebadane są również wszystkie odciski z Geraki w Lakonii (łącznie osiem), stanowiska z okresu wczesnohelladzkiego II równoczasowego z Lerną, z którego pochodzi ok. 259 fragmentów glinianych odcisków pieczęci (Weingarten 2000; Weingarten et al. 1999; Weingarten et al. 2011). Większość stanowiły gliniane pieczęcie nakładane na wylewy naczyń uprzednio przykryte matami lub wiklinowymi zatyczkami. W archiwum CMS znajduje się jednak tylko niewielka liczba odcisków silikonowych z glinianych pieczęci z tego stanowiska, zebrana na potrzeby publikacji pięciu odcisków pieczęci w tomie CMS VS3 (nr. 360-365). Niestety, w zbiorach CMS nie znajdują się trzy odcisków tkanin opublikowane przez G. VogelsangEastwood (1999). 
które pokazują rekordy z materiałem ilustracyjnym ${ }^{18}$. Dla odcisków tekstyliów jest to zdjęcie całego odcisku-matrycy w silikonie lub plastelinie oraz zdjęcia mikroskopowe nitek lub sznurków i tekstyliów. W przypadku większej liczby odciśniętych tekstyliów, każdy kolejny wyrób ma osobne zdjęcie. Dodatkowo wyświetlane są przerysy pieczęci (za CMS Arachne) jakie zostały odciśnięte na wierzchniej stronie glinianej matrycy $z$ odciskiem tekstylnym. Ze względu na planowaną publikację bazy w sieci oraz udział dwóch wykonawczyń z zagranicy ${ }^{19}$, językiem bazy i językiem roboczym projektu jest angielski. Wyszukiwarka bazy jest w pełni funkcjonalna i wykorzystywana w prezentowanych poniżej rozważaniach, ale przed publikacją wymaga dopracowania i uporządkowania słowników, oraz dostosowania niektórych terminów do potrzeb użytkownika, który nie jest specjalistą w archeologii włókiennictwa. Wyszukiwarka zapewnia także możliwość eksportu całości danych lub rezultatów określonego wyszukiwania do pliku Excel $\mathrm{w}$ formacie .xls.

\section{PODOBNE, ALE NIE TAKIE SAME - ODCISKI TEKSTYLIÓW Z LERNA I FAJSTOS}

Lerna w Argolidzie jest jednym z najważniejszych stanowisk z wczesnego okresu epoki brązu na lądzie greckim, również jeśli chodzi o informacje na temat wczesnych praktyk pieczętowania. Odciski ponad 100 glinianych pieczęci z Lerna pochodzą w większości z Domu z Dachówkami, budowli publicznej w typie tzw. domu korytarzowego, która pełniła, m.in., funkcję ośrodka administracyjnego dla lokalnej społeczności. Największy zespół odcisków datowany jest na koniec okresu wczesnohelladzkiego II, zakończony w Lerna przez falę pożarów, które zniszczyły Dom z Dachówkami (Heath 1958; Heath Wiencke

18 Baza „Tekstylia i pieczęcie” jest dostępna pod adresem: https://textileseals.uw.edu.pl/pl-baza-danych/ (dostęp 23.03.2021), ale tylko jej moduł z odniesieniami ikonograficznymi udostępniony został szerokiej publiczności. Dostęp do dwóch pozostałych modułów, tj. modułu z odciskami tekstylnymi oraz stemplowanymi narzędziami włókienniczymi, do czasu publikacji (odpowiednio wrzesień i grudzień 2021) wymaga logowania.

19 Są to prof. Marie-Louise Nosch z Centre for Textile Research w Kopenhadze oraz dr Olga Krzyszkowska z Institute of Classical Studies Uniwersytetu Londyńskiego.
1969; 1974). M. Heath Wiencke w swoim opracowaniu praktyk pieczętowania w Lerna (1958), wyróżniła sześć głównych typów pieczętowanych obiektów (A-E), z których większość stanowi typ A (odciski drewnianych belek złączonych sznurkiem, cf. Maran, Kostoula 2014) i B (gałki obwiązane sznurkiem).

Z Fajstos, jednego z najstarszych ośrodków pałacowych na Krecie, pochodzi najliczniejszy zbiór glinianych pieczęci w Egei, składający się z ponad 6500 obiektów. Większość z nich została znaleziona w pokoju 25 , w warstwie związanej ze zniszczeniami starszego pałacu datowanymi na okres średniominojski IIB (Fiandra 1968; 1975). Praktyki stemplowania w Fajstos stały się przedmiotem badań E. Fiandra, która na podstawie zbioru 1544 odcisków wyróżniła 16 typów obiektów podlegających powtarzającym się praktykom pieczętowania $\mathrm{w}$ przeciągu stosunkowo krótkiego czasu, np. jednego roku. Zdaniem Fiandry, 16 wyróżnionych przez nią typów odpowiada liczbie indywidualnych obiektów, takich jak gałki od drzwi i drzwiczek (typy a-m), po maty i koszyki (typy n i o), które były cyklicznie stemplowane i otwierane (Fiandra 1968, 386, 391, pewne zastrzeżenia wobec tej interpretacji, cf. Pini 1970, x-xi; Krzyszkowska 2005, 104-108). Widoczne w oglądzie makroskopowym ${ }^{20}$ podobieństwo sznurków na kolejnych odciskach tego samego, zdaniem Fiandry, przedmiotu, skłoniło ją do przypuszczeń, że również i one były ponownie używane przy kolejnym pieczętowaniu tego samego obiektu $(1968,387)$.

\section{Nitki, sznurki i rzemyki}

W tej kategorii wyrobów, z Lerna zachowały się wyłącznie ślady sznurków, których jest łącznie 42 . Większość sznurków (36 przykładów) skręcona jest $\mathrm{z}$ dwóch lub więcej elementów, zawsze w kierunku $S$, podczas gdy pojedyncze sznurki tworzące finalny wyrób skręcone są w kierunku z lub kierunek ich skrętu jest niewidoczny. Średnica sznurków została określona dla 37 odcisków i mieści się w przedziale od 2,41 do 7,03 mm²1, przy czym największą średnicę

20 Dodać należy, że E. Fiandra badała wyłącznie odciski gliniane, a więc odciski negatywowe, które są trudniejsze w interpretacji i których stan zachowania był słaby, cf. Fiandra 1975.

21 Podawane wartości pomiarów, takie jak średnica oraz kąt skrętu nitek i sznurków, o ile nie zaznaczono inaczej, odnoszą się do wartości minimalnych, mierzonych w przypadku pomiarów metrycznych do dwóch miejsc po 


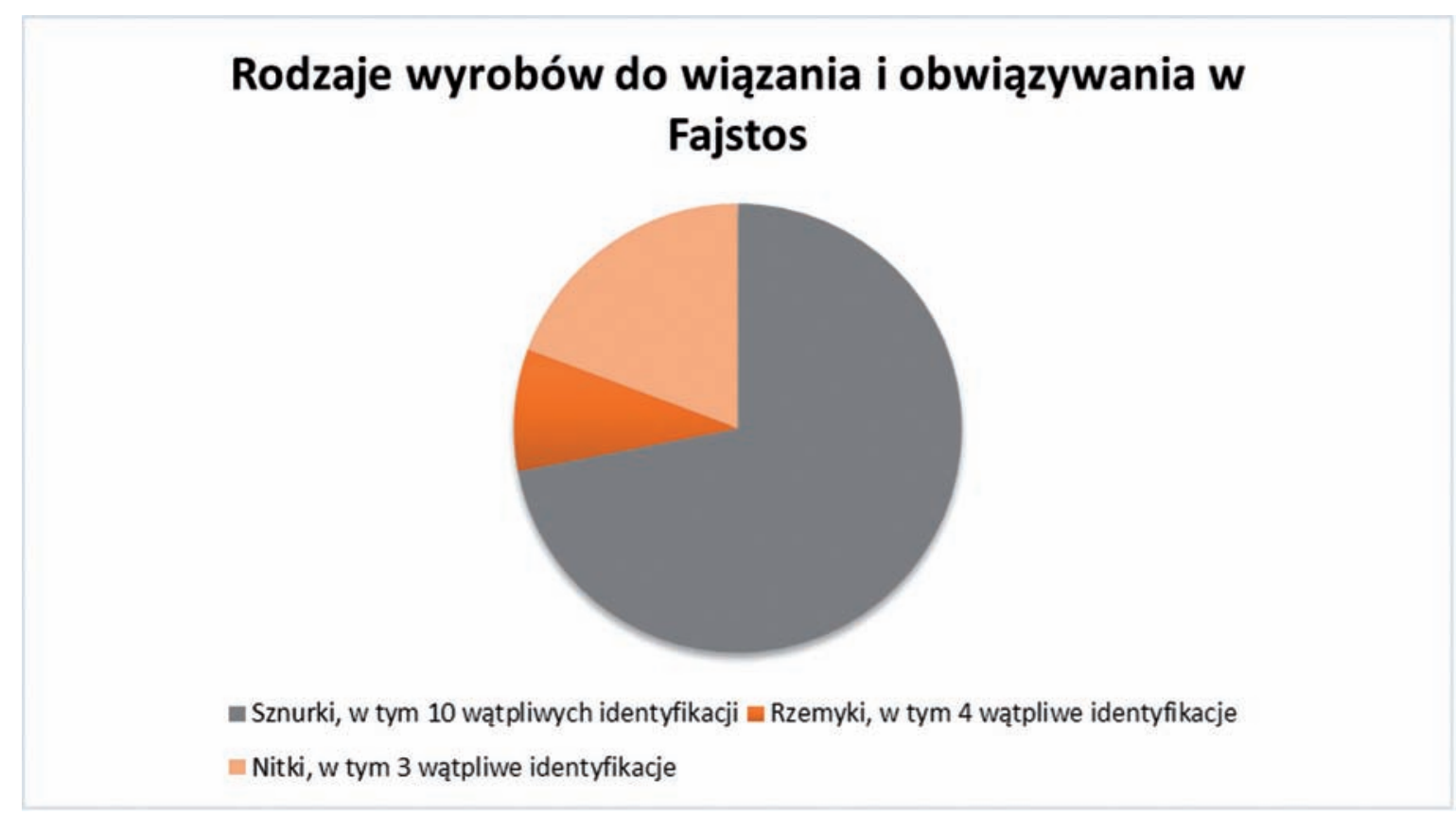

Ryc. 6. Zestawienie wyrobów tekstylnych do wiązania i obwiązywania z Fajstos

Fig. 6. Textile products to tie and wrap from Phaistos

miał wyrób skręcony z dwóch sznurków o średnicy ok. 3,68 mm (L 4.349). Średnica większości sznurków (29 przykładów) mieści się jednak w znacznie węższym przedziale pomiędzy 3-5 mm, co sugerować może zarówno pewną ich standaryzację, jak i dobór optymalny dla owijania i obwiązywania określonych przedmiotów czy obiektów. Nie zaobserwowano korelacji pomiędzy kątem skrętu a średnicą sznurka, ani pomiędzy obwiązywanym przedmiotem a średnicą sznurka: cieńsze i grubsze sznurki używane były zarówno do wiązania drewnianych belek, jak i mniejszych gałek od drzwi. Kąt skrętu, zmierzony dla 35 odciśniętych sznurków, mieści się w przedziale 19$53^{\circ}$, przy czym znowu, większość sznurków (27 przykładów) cechuje podobny stopień skręcenia, mieszczący się $\mathrm{w}$ przedziale między $20-50^{\circ}$. Porównanie minimalnej i maksymalnej średnicy oraz kąta skrętu może pośrednio wskazywać na jakość wyrobów - mniejsze różnice pomiędzy obiema wartościami sugerują umiejętności wytwórcze, które pozwalały na przędzenie lub skręcanie sznurków o podobnych parametrach na ich całej długości. Porównanie minimalnej i maksymalnej średnicy i kąta skrętu było możli-

przecinku. Wszędzie tam, gdzie było to możliwe zdejmowałam co najmniej trzy pomiary dla każdego z odcisków, dokumentując w bazie danych wyniki brzegowe - wartość minimalną i maksymalną. we dla, odpowiednio, 18 i 13 odcisków. W przypadku średnicy, różnice wynosiły od 0,05 do $1,94 \mathrm{~mm}$, ale różnice powyżej $1 \mathrm{~mm}$ cechują tylko dwa przykłady, wśród pozostałych sznurków największa różnica wynosiła zaledwie $0,68 \mathrm{~mm}$. Dla kąta skrętu różnice między wartościami minimalnymi i maksymalnymi mieściły się $\mathrm{w}$ przedziale 1-15 stopni, ale ponownie, w 10 z 13 zbadanych sznurków, maksymalna różnica w kącie skręty wynosiła zaledwie 5 stopni.

Wśród odcisków z Fajstos, również przeważają sznurki (82 przykłady, w tym 10 wątpliwych identyfikacji), ale do obwiązywania i wiązania używano także nitek (22 przykłady, w tym trzy wątpliwe identyfikacje) oraz rzemyków (dziewięć przykładów, w tym cztery wątpliwe identyfikacje, ryc. 6). Większość utrwalonych w odciskach wyrobów, podobnie jak w Lerna, była skręcana lub przędziona, z wyjątkiem sześciu odcisków sznurków i czterech odcisków nitek, które wyglądają jak plecionki i sugerują nową, niewystępującą wcześniej technikę produkcji (ryc. 7). Wśród sznurków dwojonych lub trojonych nadal przeważa kierunek skrętu $\mathrm{S}$, ale trzy tego typu sznurki (PH 710, PH 713, PH 833?) są skręcone w kierunku Z. Średnica zmierzona na 72 odciskach wynosi od 2,05 do $6,05 \mathrm{~mm}$, przy czym znów, większość sznurków (62 przykłady) ma średnice mieszczące się w węższym przedziale między 2 a $4 \mathrm{~mm}$. Kąt skrętu, uchwytny dla 62 odcisków sznurków, 

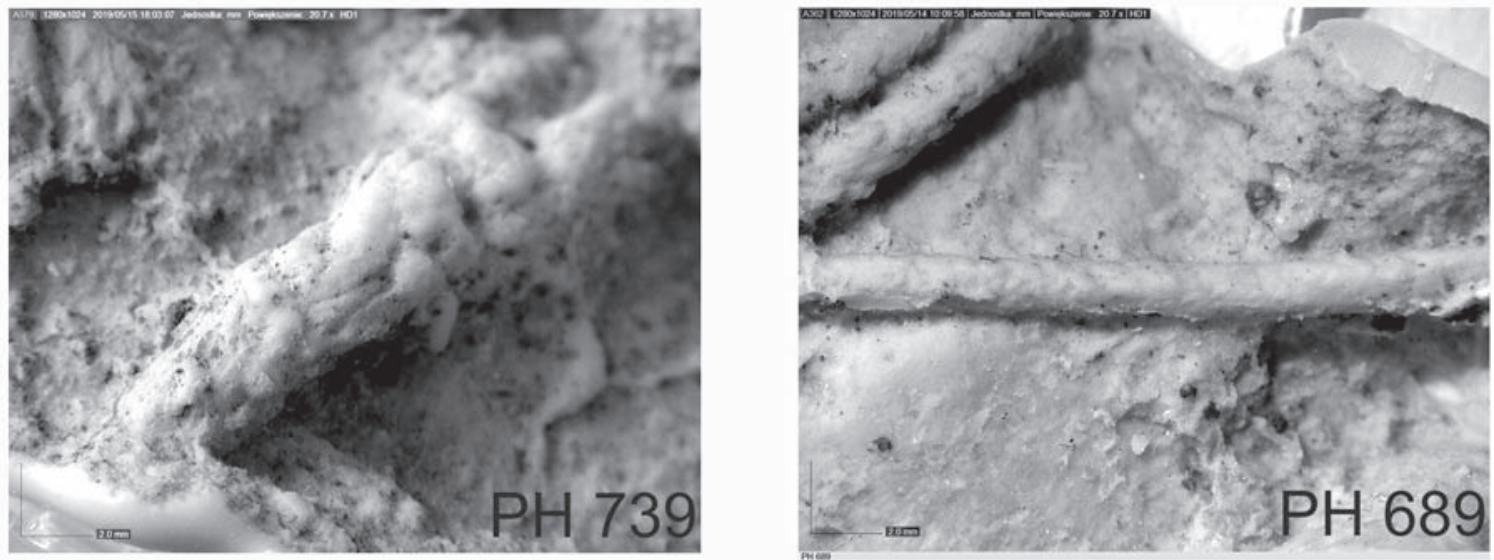

Ryc. 7. Plecione (?) sznurek i nitka z Fajstos. Odciski - CMS Heidelberg, fot. A. Ulanowska Fig. 7. Braided (?) cord and thread from Phaistos. Casts - CMS Heidelberg, photo by A. Ulanowska

mieści się w szerokim przedziale od 15 do $58^{\circ}$, ale i tu większość wyrobów (42 przykłady) charakteryzuje wyraźnie mniejszy przedział między 25 a $45^{\circ}$. Porównanie minimalnej i maksymalnej średnicy oraz kąta skrętu możliwe było dla, odpowiednio, 47 i 24 przykładów. Różnice w średnicy wynoszą od 0,04 do 2,94 mm, przy czym aż dla 40 wyrobów różnica ta nie przekracza $0,57 \mathrm{~mm}$, ze średnią $0,26 \mathrm{~mm}$. Różnice w kącie skrętu wynoszą od 1 do $27^{\circ}$, przy czym dla 15 sznurków zmierzona różnica nie przekracza $6^{\circ}$.

W grupie nitek z Fajstos są trzy odciski, które dokumentują wyroby na granicy między nitką i sznurkiem, tzn. na podstawie minimalnych wartości średnicy są to, wg. przyjętej klasyfikacji nitki, ale wg maksymalnych wartości - sznurki. Przeważają nitki skręcone pojedynczo (14 przykładów), w większości, ale nie wyłącznie, w kierunku z (cztery odciski wskazują na skręt s). Średnica nitek, zmierzona na wszystkich odciskach, mieści się w przedziale od 0,4 do $1,94 \mathrm{~mm}$, przy czym 7 odcisków ma średnicę poniżej $1 \mathrm{~mm}$. Różnica między minimalną i maksymalną średnicą w grupie nitek nie przekracza $0,64 \mathrm{~mm}$. Kąt skrętu, zmierzony na 15 odciskach, wynosi od 21 do $51^{\circ}$. W kategorii rzemyków, średnica lub szerokość skórzanych pasków mieści się w przedziale od 2,02 do $5,07 \mathrm{~mm}$, a więc jest porównywalna ze średnicą sznurków.

\section{Tkaniny}

Odciski tkanin na spodach glinianych pieczęci zamykających wylewy naczyń, częste w praktykach stemplowania na Bliskim Wschodzie (cf. Andersson Strand et al. 2017), występują także w Lerna (siedem przykładów) i Fajstos (23 przykłady), ale na obu stanowiskach ten typ pieczęci stanowi wyraźną mniejszość (por. ryc. 1.2). Większość odcisków rozpoznanych jako tkaniny lub prawdopodobnie tkaniny znajduje się w miejscach mniej oczywistych - pomiędzy witkami wiklinowych koszyków, po bokach owiniętych lub obwiązanych sznurkami gałek oraz na brzegach glinianej matrycy, często na powierzchni prostopadłej do gałki owiniętej sznurkiem (ryc. 1). Obecność odcisków tkanin w takich miejscach może być, przynajmniej częściowo, wyjaśniona przez roboczo przyjętą hipotezę, która zakłada, że spody glinianych pieczęci mogły także utrwalać tkaniny, którymi owijano glinę używaną w praktykach pieczętowania, co zapobiegałoby utracie wilgoci i tym samym właściwości plastycznych. Bryłki gliny mogły być także formowane do stemplowania na podłożu pokrytym tkaniną, np. wprost na kolanie osoby, która przygotowywała pieczęć. Trzecią możliwością mogą być wreszcie przypadkowe odciski fragmentów ubrania, np. rękawów, osób które zajmowały się pieczętowaniem. Wszystkie te przypuszczenia wymagają dalszej weryfikacji eksperymentalnej.

Fragmentarycznie zachowane odciski tkanin są zwykle mało czytelne, co skutkuje znaczną liczbą wątpliwych identyfikacji w tej grupie wyrobów włókienniczych. Z Lerna pochodzi 39 odcisków tkanin, w tym 13 wątpliwych identyfikacji. Jedynym rozpoznanym splotem jest splot płócienny. Średnica nitek, uchwytna na 33 odciskach, wynosi od 0,19 do $0,56 \mathrm{~mm}$, przy czym różnice pomiędzy pomiarem minimalnym i maksymalnym mieszczą się w niewielkim przedziale od 0,01 do $0,2 \mathrm{~mm}$. Nitek o średnicy mniejszej niż $0,3 \mathrm{~mm}$ jest zaledwie pięć, średnia dla 


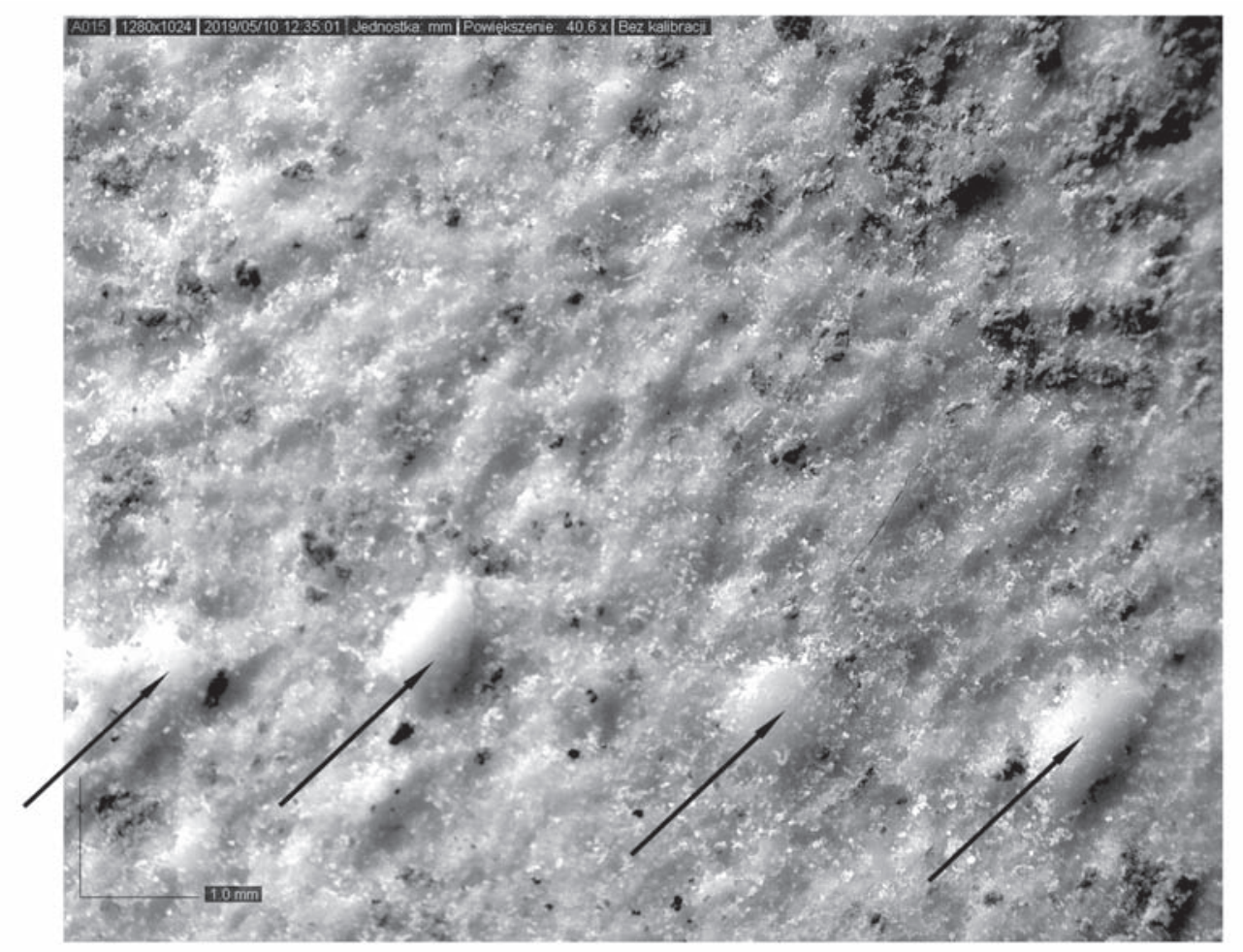

Ryc. 8. Odcisk tkaniny z możliwą dekoracją (PH 697). Prawdopodobne ślady grubszej nitki wprowadzonej w tkaninę w regularnych odstępach zaznaczone są strzałkami. Odcisk - CMS Heidelberg, fot. A. Ulanowska

Fig. 8 Imprint of a possibly decorated textile (PH 697). Traces of a possibly thicker thread inserted in regular intervals are indicated by arrows. Cast - CMS Heidelberg, photo by A. Ulanowska

pomiarów średnicy nitek w odciśniętych tkaninach $\mathrm{z}$ Lerna to $0,38 \mathrm{~mm}$. W nielicznych przypadkach możliwa była próba oszacowania liczby nitek na $\mathrm{cm}^{2}$ tkaniny, z reguły podawana dla obu systemów nitek łącznie, na podstawie obliczeń z niewielkich odcinków o długości 2 lub 5 mm. Wśród odcisków z Lerna takie szacunki możliwe były dla zaledwie czterech tkanin i wynoszą one $30 \mathrm{n} / \mathrm{cm}$ (L 4.364 i L 4.381) oraz $40 \mathrm{n} / \mathrm{cm}$ (L 4.375 i L 4.397).

Wśród tekstyliów z Fajstos znajduje się aż 124 możliwych odcisków tkanin, ale tylko 69 identyfikacji wydaje się być pewnych, w tym trzy odciski, które mogą być także odciskami mat. Pomimo pewnej regularności sugerującej tkaną strukturę, w przypadku pozostałych odcisków identyfikacja $\mathrm{z}$ tkaniną pozostaje wątpliwa, nawet jeśli możliwe było zdjęcie pomiarów sugerujących średnicę pojedynczych nitek (36 ze 101 odcisków). Wszystkie odciśnięte tkaniny wykonane były w splocie płóciennym. Jedynie

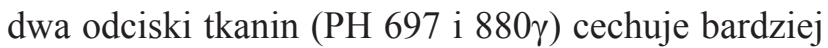
otwarta, przypominająca siatkę budowa. Tkanina odciśnięta na spodzie glinianej pieczęci PH 697 jest też jedynym przykładem ewentualnej dekoracji w postaci grubszej nitki o średnicy ok. 0,67 mm, wprowadzonej w regularnych odstępach w strukturę delikatnej tkaniny z nitek o średnicy ok. 0,31 mm (ryc. 8). Kierunek skrętu nitek rozpoznany został z wątpliwościami na 5 odciskach i tylko w jednym przypadku sugerować może skręt s (PH 714). Średnica nitek w tkaninach z Fajstos mieści się w przedziale od 0,15 do $1,71 \mathrm{~mm}$, przy czym najwyższe pomiary $0,96 \mathrm{~mm}$ i 1,71 mm odpowiadają średnicom nitek/elementów w ewentualnych matach. Najwięcej odcisków tkanin (73 przykłady) miało nitki o średnicach mieszczących się w węższym przedziale pomiędzy 0,2 a $0,45 \mathrm{~mm}$. Różnica między pomiarami minimalnymi i maksymalnymi wynosiła od 0,04 do $0,66 \mathrm{~mm}$ ze średnią $0,11 \mathrm{~mm}$. Liczba nitek na $\mathrm{cm}^{2}$ oszacowana została dla 34 odcisków i wynosi od 20 do $80 \mathrm{n} / \mathrm{cm}$, przy czym gęstość większości tkanin (25 przykładów) mieści się w węższym przedziale między 30 a $50 \mathrm{n} / \mathrm{cm}$. Szacunki te przewyższają znaną gęstość tkanin archeologicznych z Egei (cf. Spantidaki, Moulheart 2012, 197; Andersson Strand, Nosch 2015, Appendix B: Bronze Age Greece), ale, jak wspomniano powyżej, wszystkie pomiary zdejmowane $\mathrm{z}$ odcisków są wyłącznie przybliżone. 


\section{UWAGI PODSUMOWUJĄCE}

Zbiór odcisków tekstylnych ze spodów glinianych pieczęci zgromadzony w Archiwum CMS w Heidelbergu stanowi bez wątpienia nowe źródło wiedzy o wyrobach włókienniczych w Grecji epoki brązu. Choć w ramach projektu „Tekstylia i pieczęcie" zbiór ten przebadany został jedynie częściowo, pełne informacje pozyskane $\mathrm{z}$ dwóch stanowisk: Lerna w Argolidzie i Fajstos na Krecie, stanowią istotne uzupełnienie obrazu produkcji włókienniczej. W Lerna odciski tekstyliów na spodach glinianych pieczęci stanowią jedyne materialne pozostałości wyrobów włókienniczych. Z okolic Fajstos jednak, poza wspomnianą słomianką, na brązowej płytce pochodzącej z jednego z grobów w Kalyvia datowanych na okres późnominojski III zachował się fragment sznurka (Militello 2012; Margariti 2012). Sznurek skręcony jest wielostopniowo: trzy pojedyncze Z-skrętne nitki łączone były w sznurek S-skrętny, który następnie został zdwojony w kierunku Z. Średnica sznurka wynosi $1,58 \mathrm{~mm}$, kąt skrętu $25^{\circ}$, budowa włókna sugeruje surowiec pochodzenia roślinnego, jak np. len lub konopie (Margariti 2012). Pomimo znacznie późniejszej daty, parametry te porównywalne są z parametrami średniominojskich sznurków odciśniętych na spodach glinianych pieczęci, łącznie z unikalnym dla Grecji epoki brązu kierunkiem skrętu Z.

Stopień szczegółowości informacji, jakie uzyskać można z odcisków, zależy od wielu czynników, ale nawet w przypadku doskonale zachowanych odcisków i wysokiej jakości masy ceramicznej, która tworzyła glinianą matrycę, informacje te podlegają istotnym ograniczeniom. Jak dowodzą badania eksperymentalne, wszystkie pomiary zdejmowane z odcisków należy traktować jako pomiary przybliżone, które mogą być zarówno mniejsze, jak i większe od wartości mierzonych na oryginalnym wyrobie. Wątpliwości też budzi możliwość jednoznacznego rozpoznania surowców włókienniczych. Zaproponowane powyżej kryteria rozpoznawania surowców po takich cechach, jak mikrostruktura włókien, rodzaj powierzchni, łamliwość i charakterystyczne uszkodzenia czy przekrój włókien/wyrobów (tabela 2) pomagają uporządkować wnioskowanie, ale tylko w niektórych wypadkach sugerować mogą konkretny surowiec. Nadal jednak odciski tekstyliów na spodach glinianych pieczęci dostarczają unikatowych informacji o indywidualnych wyrobach: technice produkcji, kierunku, kącie skrętu nitek i sznurków oraz splotach tkanin.
Istotna jest także liczebność odcisków: 199 odcisków tekstylnych z dobrze datowanych kontekstów wyłącznie z Lerna i Fajstos, stanowi nową jakość badawczą $\mathrm{w}$ porównaniu $\mathrm{z}$ ok. 30 zachowanymi tkaninami archeologicznymi ${ }^{22}$, pochodzącymi z obszaru Grecji z całej epoki brązu (Andersson Strand, Nosch 2015, Apendix B: Greece). Porównanie minimalnych i maksymalnych pomiarów indywidualnych odcisków tekstyliów z Lerna i Fajstos sugeruje znaczną spójność, a zatem i techniczne zaawansowanie wyrobów w obydwu ośrodkach. Przy podobnych praktykach pieczętowania i magazynowania, w Fajstos używano jednak bardziej różnorodnych wyrobów i technik, takich jak przędzenie lub skręcanie w obu kierunkach: $\mathrm{S}$ i Z oraz wyplatanie sznurków i nitek. Również jeśli chodzi o surowce włókiennicze, odciski z Fajstos wydają się wskazywać na większą rozmaitość, potwierdzając użycie materiałów pochodzenia zwierzęcego. Analiza sznurków, z przewagą wyrobów o średnicach między 3 a 5 mm w Lerna oraz między 2 a 4 mm w Fajstos, sugeruje częstsze używanie cieńszych sznurków w Fajstos, potwierdzone dodatkowo obecnością wyrobów klasyfikowanych jako nitki. Również kąt skrętu wydaje się być tu bardziej jednorodny, choć niekoniecznie wyższy niż w Lerna. W przypadku tkanin, między Lerna a Fajstos nie ma zauważalnych różnic w średniej grubości nitek. Co prawda z Fajstos jest nieco większa grupa tkanin z nitek o średnicy poniżej $0,3 \mathrm{~mm}$ (14 przy pięciu analogicznych przykładach z Lerna), ale też i odcisków tkanin z Fajstos jest ponad trzykrotnie więcej.

Opisane różnice wskazywać mogą na postęp technologiczny w produkcji włókienniczej uchwytny, po raz pierwszy, w materiale archeologicznym. Odciski tekstylne z Fajstos, młodsze o ok. 750 lat od tych z Lerna, dowodzą większej różnorodności technik, surowców i, być może, lepszej jakości technicznej wyrobów. Pamiętać jednak należy, że z Fajstos zachowało się znacznie więcej odcisków tekstyliów i praktyki stemplowania były tam bardziej intensywne niż w Lerna, co nakazuje zachować ostrożność przy wyciąganiu ogólniejszych wniosków z zaobserwowanych różnic w obu zespołach zabytków.

Wreszcie, badania nad odciskami tekstyliów na spodach glinianych pieczęci z Grecji epoki brązu otwierają szereg nowych pytań badawczych. Trud-

22 Pamiętać należy, że liczba ta jest w rzeczywistości większa, ponieważ wiele fragmentów tekstyliów archeologicznych czeka na opublikowanie. 
ne do wyjaśnienia miejsca występowania odcisków tkanin związane być mogą ze sposobem przechowywania wilgotnej gliny i metodą formowania pieczęci - kwestiami nieobecnymi, jak dotąd, w literaturze przedmiotu. Wydaje się też, że pierwotna koncepcja E. Fiandra, która zakładała, że 16 typów pieczęci z Fajstos odpowiada 16 przedmiotom, które były wielokrotnie zamykane i otwierane $\mathrm{z}$ użyciem tych samych sznurków, nie znajduje potwierdzenia w wielkiej rozmaitości nitek i sznurków zachowanych na odciskach. Choć nie można wykluczyć, że część odcisków rzeczywiście dokumentuje te same wyroby (ponownie używane przy kolejnym pieczętowaniu), porównanie parametrów sznurków o podobnych średnicach wskazuje na ich techniczne różnice, jak inny kąt skrętu czy inna mikrostruktura włókien, co oznacza, że uchwycenie powtarzalnego użycia tych samych wyrobów wymaga bardziej złożonego podejścia badawczego. Dalsza analiza odcisków tekstyliów na spodach glinianych pieczęci może też pomóc w wyjaśnieniu nierozstrzygniętych dotąd pytań o liczbę osób biorących udział w bieżących praktykach sfragistycznych i liczbę pieczęci, którymi posługiwały się te osoby. Analiza sposobu obwiązywania gałek i drzwi oraz stosowanych węzłów powinna dostarczyć nowych danych dla wyróżnienia indywidualnych „rąk”, które brały udział w praktykach stemplowania, a tym samym przyczynić się do zdefiniowania zakresu kompetencji administracyjnych osób używających pieczęci.

\section{BIBLIOGRAFIA}

Alberti M.E. (2017). A measured world? Measures in Minoan daily life. W: A.M. Jasink, J. Weingarten, S. Ferrara (red.), Non-Scribal Communication Media in the Bronze Age Aegean and Surrounding Areas (3-39). Firenze: Periploi 9.

Andersson Strand E. (2015). The basics of textile tools and textile technology - from fibre to fabric. W: E. Andersson Strand, M.-L. Nosch (red.), Tools, Textiles and Contexts: Investigating Textile Production in the Aegean and Eastern Mediterranean Bronze Age (39-60). Oxford, Philadelphia: Ancient Textiles Series 21.

Andersson Strand E., Nosch M.-L. (red.). (2015). Tools, Textiles and Contexts: Investigating Textile Production in the Aegean and Eastern Mediterranean Bronze Age. Oxford, Philadelphia: Ancient Textiles Series 21.

Andersson Strand E., Breniquet C., Michel C. (2017). Textile imprints on bullae from Kültepe. W: F. Kulakoğlu, G. Barjamovic (red.), Movements, resources, interaction, Proceedings of the 2nd Kültepe International Meeting 26-30 July 2015, Studies Dedicated to Klass Veenhof (87-104). Turnhout: KIM 2.

Barber E.J.W. (1991). Prehistoric Textiles. The Development of Cloth in the Neolithic and Bronze Ages with Special Reference to the Aegean. Princeton: Princeton University Press.

Boloti T. (2017). Offering of cloth and/or clothing to the sanctuaries: A case of ritual continuity from the 2 nd to the1st millennium BCE in the Aegean. W: C. Brøns,
M.-L. Nosch (red.), Textiles and Cult in the Ancient Mediterranean (3-16). Oxford, Philadelphia: Ancient Textiles Series 31.

Brogan T.M., Betancourt P.P., Apostolakou V. (2012). The purple dye industry of Eastern Crete. W: M.-L. Nosch, R. Laffineur (red.), KOSMOS. Jewellery, Adornment and Textiles in the Aegean Bronze Age. Proceedings of the $13^{\text {th }}$ International Aegean Conference, University of Copenhagen, Danish National Research Foundation's Centre for Textile Research, 21-26 April 2010 (187-192). Leuven, Liège: Aegaeum 33.

Burke B (1997). The organization of textile production on Bronze Age Crete. W: R. Laffineur, P.P. Betancourt (red.), TEXNH, Craftsmen, Craftswomen and Craftsmanship in the Aegean Bronze Age, Proceedings of the $6^{\text {th }}$ International Aegean Conference Philadelphia, Temple University, 18-21 April 1996 (413-422). Liège, Austin: Aegaeum 16.

Burke B. (2010). From Minos to Midas: Ancient Cloth Production in the Aegean and in Anatolia. Oxford, Oakville: Ancient Textiles Series 7.

Crowley J.L. (2012). Prestige clothing in the Bronze Age Aegean. W: M.-L. Nosch, R. Laffineur (red.), KOSMOS. Jewellery, Adornment and Textiles in the Aegean Bronze Age. Proceedings of the $13^{\text {th }}$ International Aegean Conference, University of Copenhagen, Danish National Research Foundation's Centre for Textile Research, 21-26 April 2010 (231-238). Leuven, Liège: Aegaeum 33. 
Cutler J. (2016). Fashioning identity: Weaving technology, dress and cultural change in the Middle and Late Bronze Age southern Aegean. W: E. Gorogianni, P. Pavúk, L. Girella (red.), Beyond Thalassocracies. Understanding Processes of Minoanisation and Mycenaeanisation in the Aegean (172-185). Oxford, Philadelphia: Oxbow Books.

†Cutler J. (2019). Arachne's Web: Women, weaving and networks of knowledge in the Bronze Age southern Aegean. The Annual of the British School of Athens, 114, 1-14. https://doi.org/10.1017/S0068245419000121.

†Cutler J. (2021 w druku). Crafting Minoanisation: Textiles, Crafts Production and Social Dynamics in the Bronze Age Southern Aegean. Oxford, Philadelphia: Ancient Textile Series 33.

Del Freo M., Nosch M.-L., Rougemont F. (2010). The terminology of textiles in the Linear B tablets, including some considerations on Linear A logograms and abbreviations. W: C. Michel, M.-L. Nosch (red.), Textile Terminologies in the Ancient Near East and Mediterranean from the Third to the First Millennia BC (338373). Oxford, Oakville: Ancient Textiles Series 8.

Fiandra E. (1968). A che cosa servivano le cretule di Festòs.

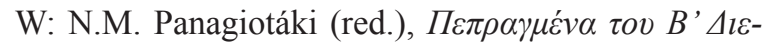

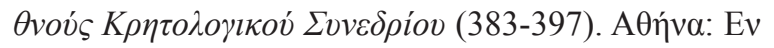
A $\theta$ ívals.

Fiandra E. (1975). Ancora a proposito delle cretule di Festòs: connessione tra i sistemi amministrativi centralizzati e l'uso delle cretule nell'età del bronzo. Bollettino d'Arte, 60, 1-25.

Grömer K., Kern D. (2010). Technical data and experiments on corded ware. Journal of Archaeological Science, 37, 3136-3145. 10.1016/j.jas.2010.07.015.

Harlow M., Michel C., Nosch, M.-L. (red.) (2014). Prehistoric, Ancient Near Eastern and Aegean Textiles and Dress: An Interdisciplinary Anthology. Oxford, Philadelphia: Ancient Textiles Series 18.

Heath M.C. (1958). Early Helladic clay sealings from the House of the Tiles at Lerna. Hesperia, 27(2), 81-121.

Heath Wiencke M. (1969). Further seals and sealings from Lerna. Hesperia, 38(4), 500-521.

Heath Wiencke M. (1974). The Lerna Sealings. W: F. Matz (red.), Die kretisch-mykenische Glyptik und ihre gegenwärtigen Probleme (169-163). Boppard: CMS Beiheft 0.

Jones B.R. (2015). Ariadne's Threads: The Construction and Significance of Clothes in the Aegean Bronze Age. Leuven, Liège: Aegaeum 38.

Killien J.T. (2007). Cloth production in Late Bronze Age Greece: the documentary evidence. W: C. Gillis, M.-L. Nosch (red.), Ancient Textiles: Production,
Craft and Society. Proceedings of the First International Conference on Ancient Textiles, held at Lund Sweden and Copenhagen, Denmark, on March 19-23, 2003 (50-58). Oxford: Ancient Textiles Series 1.

Koh A.J., Betancourt P.P, Pareja M.N., Brogan T.M., Apostolakou V. (2016). Organic residue analysis of pottery from the dye workshop at Alatsomouri-Pefka, Crete. Journal of Archaeological Science: Reports, 7, 536538, http://dx.doi.org/10.1016/j.jasrep.2014.12.005

Krzyszkowska O. (2005). Aegean Seals: An Introduction. London: Bulletin of the Institute of Classical Studies Supplement 85.

Krzyszkowska O. (2019). Some remarks on the use of textiles and organic materials in Minoan sealing practices. London. Opracowanie dla projektu „Tekstylia i pieczęcie" (maszynopis).

Krzyszkowska O. (2020). Some remarks on the use of textiles and organic materials in Mycenaean sealing practices. London. Opracowanie dla projektu „Tekstylia i pieczęcie" (maszynopis).

Laurito R. (2007a). Cretulae and sealed objects from minor dumping areas in the 4th millennium palace at Arslantepe. W: M. Frangipane (red.), Arslantepe. Cretulae: An Early Centralised Administrative System Before Writing (126-147). Rome: Arslantepe vol. V.

Laurito R. (2007b). Ropes and textiles. W: M. Frangipane (red.), Arslantepe. Cretulae: An Early Centralised Administrative System Before Writing (381-394). Rome: Arslantepe vol. V.

Manning S.W. (2010). Chronology and terminology. W: E.H. Cline (red.), The Oxford Handbook of the Bronze Age Aegean (11-28). Oxford: Oxford University Press.

Maran J., Kostoula M. (2014). The spider's web: Innovation and society in the Early Helladic 'Period of the Corridor Houses'. W: Y. Galanakis, T. Wilkinson,

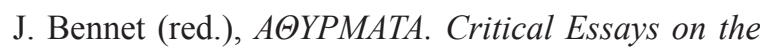
Archaeology of the Eastern Mediterranean in Honour of E. Susan Sherratt (141-158). Oxford: Archaeopress.

Margariti C. (2012). Preliminary Report on the Bronze Age Fibre Find from Phaistos: Results of the Study of a Metal Plate with Traces of String (1903.688) from the Archaeological Museum of Heraklion. W: M. Andrianakis, P. Varthalitou, I. Tzachili (red.),

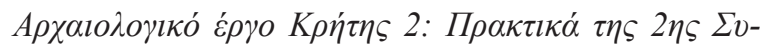

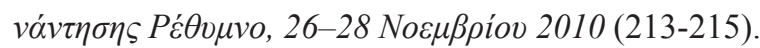

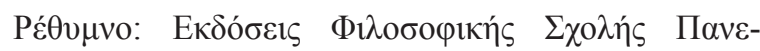

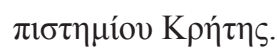

Margariti C., Nosch M.-L., Skals I. (2012). Preliminary Reprot on the Bronze Age Fibre Find from Pha- 
istos. W: M. Andrianakis, P. Varthalitou, I. Tzachili

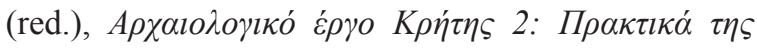

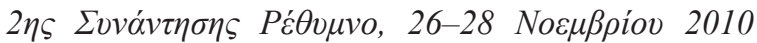

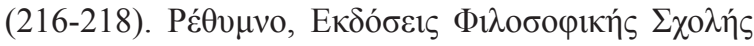

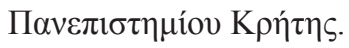

Michailidou A. (1990). The lead weights from Akrotiri: the archaeological record. W: D.A. Hardy, C.G. Doumas, J.A. Sakellarakis, P.M. Warren (red.), Thera and the Aegean World III. Proceedings of the Third International Congress, Santorini, 3-9 September 1989 (407419). London: Thera Foundation.

Michałowska M. (2006). Leksykon włókiennictwa. Warszawa: Krajowy Ośrodek Badań i Dokumentacji Zabytków w Warszawie.

Militello P. (2007). Textile industry and Minoan palaces. W: C. Gillis, M.-L.B. Nosch (red.), Ancient Textiles, Production, Craft and Society, Proceedings of the First International Conference on Ancient Textiles, held at Lund Sweden and Copenhagen, Denmark, on March 19-23, 2003 (36-45). Oxford: Ancient Textiles Series 1.

Müller W. (1997). Terminologie und Typologie der Tonplomben. W: W. Müller, J.-P. Olivier, I. Pini, A. Sakellariou (red.), Die Tonplomben aus dem Nestorpalast von Pylos (53-66). Mainz: Verlag Philipp Von Zabern.

Müller W. (1999). Die Tonplomben und andere gestempelte Tonobjekte. W: W. Müller, I. Pini (red.), Iraklion Archäologisches Museum: die Siegelabdrücke von Aj. Triada und anderen zentral- und ostkretischen Fundorten, unter Einbeziehung von Funden aus anderen Museen (339-400). Berlin: CMS II,6.

Müller W. (2002). Untersuchungen zur Typologie, Funktion und Verbreitung der Tonplomben von Knossos. W: M.A.V. Gill, W. Müller, I. Pini (red.), Iraklion Archäologisches Museum (24-93). Mainz: CMS II,8.

Müller W. (2004). Bemerkungen zu den Tonplomben und Siegelabdrücken auf Gefässen und,Gewichten'. W: I. Pini (red.), Kleinere griechische Sammlungen: Neufunde aus Griechenland und der westlichen Türkei (43-60). Mainz: CMS V Suppl. 3.

Müller W., Pini I. (1997). Die ,Schnüre‘ in den Plomben und die Gegenstandsabdrücke. W: W. Müller, J.-P. Olivier, I. Pini, A. Sakellariou (red.), Die Tonplomben aus dem Nestorpalast von Pylos (67-69). Mainz: Verlag Philipp Von Zabern.

Nosch M.-L. (2012). The textile logograms in the Linear B tablets: les idéogrammes archéologiques des textiles. W: P. Carlier, C. de Lamberterie, M. Egetmeyer, N. Guilleux, F. Rougemont, J. Zurbach (red.), Études Mycéniennes 2010. Actes du XIII Colloque Interna- tional sur les textes égéens, Sèvres, Paris, Nanterre, 20-23 septembre 2010 (303-346). Pisa, Rome: Biblioteca di Pasiphae 10.

Nosch M.-L., Laffineur R. (red.) (2012). KOSMOS. Jewellery, Adornment, and Textiles in the Aegean Bronze Age. Proceedings of the $13^{\text {th }}$ International Aegean Conference, University of Copenhagen, Danish $\mathrm{Na}$ tional Research Foundation's Centre for Textile Research, 21-26 April 2010. Leuven, Liège: Aegaeum 33.

Nosch M.-L., Ulanowska A. (2021). The materiality of the Cretan Hieroglyphic script: textile production-related referents to hieroglyphic signs on seals and sealings from Middle Bronze Age Crete. W: P. Boyes, P. Steele, N.E. Astoreca (red.), The Social and Cultural Contexts of Historic Writing Practices (73-100). Oxford, Philadelphia: Oxbow Books.

Palaima T. (1990). Aegean Seals, Sealings and Administration. Proceedings of the NEH-Dickson Conference of the Program in Aegean Scripts and Prehistory of the Department of Classics, University of Texas at Austin, January 11-13, 1989. Liège: Aegaeum 5.

Panagiotakopulu E., Buckland P.C., Day P.M., Doumas C., Sarpaki A., Skidmore P. (1997). A lepidopterous cocoon from Thera and evidence for silk in the Aegean Bronze Age. Antiquity, 71, 420-429.

Panagiotopoulos D. (2014). Mykenische Siegelpraxis: Funktion, Kontext und administrative Verwendung mykenischer Tonplomben auf dem griechischen Festland und Kreta. München: Athenaia 5.

Rast-Eicher A. (2007). Textilien, Wolle, Schafe der Eisenzeit in der Schweiz. Basel: Archäologie Schweiz.

Rougemont F. (2014). Sheep rearing, wool production and management in Mycenaean written documents. W: C. Breniquet, C. Michel (red.), Wool Economy in the Ancient Near East and the Aegean. From the Beginnings of Sheep Husbandry to Institutional Textile Industry (340-370). Oxford, Philadelphia: Ancient Textiles Series 17.

Shaw M.C., Chapin A.P. (2016). Woven Threads: Patterned Textiles of the Aegean Bronze Age. Oxford, Philadelphia: Ancient Textile Series 22.

Skals I., Möller-Wiering S., Nosch M.-L. (2015). Survey of archaeological textile remains from the Aegean and Eastern Mediterranean. W: E. Andersson Strand, M.-L. Nosch (red.), Tools, Textiles and Contexts: Investigating Textile Production in the Aegean and Eastern Mediterranean Bronze Age (61-74). Oxford, Philadelphia: Ancient Textiles Series 21.

Spantidaki Y., Moulherat Ch. (2012). Greece. W: M. Gleba, U. Mannering (red.), Textiles and Textile Production 
in Europe: From Prehistory to AD 400 (185-200). Oxford, Oakville: Ancient Textiles Series 11.

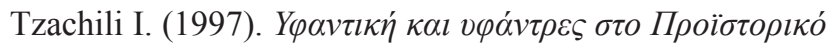

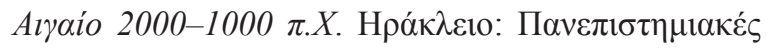

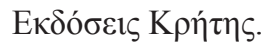

Ulanowska A. (2016). Włókiennictwo Grecji epoki brązu w (akademickiej) praktyce. Nowe refleksje nad zastosowaniem archeologii doświadczalnej w nauczaniu technologii dawnego włókiennictwa. W: M. Figueira, K. Żebrowska (red.), International Course in Archaeology. "Papers in Mediterranean Archaeology" (215-234). Catania: Syndesmoi 5.

Ulanowska A. (2017). Textile technology and Minoan glyptic: representations of loom weights on Middle Minoan prismatic seals. W: K. Żebrowska, A. Ulanowska, K. Lewartowski (red.), Sympozjum Egejskie. Papers in Aegean Archaeology, vol. 1 (57-66). Warsaw: Institute of Archaeology, University of Warsaw.

Ulanowska A. (2018). But how were they made? More about patterned textiles in the Aegean Bronze Age. Fasciculi Archaeologiae Historicae, 31, 39-54.

Ulanowska A. (2020a). A chaîne opératoire as a framework for investigating prehistoric textile production: Production of clay textile tools in Middle Bronze Age Crete as a 'troublesome' case study. Archaeological Review from Cambridge, 35.1, 212-226.

Ulanowska A. (2020b). Textiles and Seals: Recognising the relationship between textile production and seals, and sealing practices in Bronze Age Greece. Revue de l'Archéologie du Vêtement et du Costume, 1, 1-25.

Ulanowska A., Siennicka M. (2018). The economics of textiles in Bronze Age Greece. W: M.S. Busana, M. Gleba, F. Meo, A.R. Tricomi (red.), Textiles and Dyes in the Mediterranean Economy and Society. Proceedings of the VIth International Symposium on Textiles and Dyes in the Ancient Mediterranean World (Padova-Este-Altino, Italy 17-20 October 2016) (39-48). València: PURPUREAE VESTES VI.
Vakirtzi S., Georma F., Karnava A. (2018). Beyond textiles: alternative uses of twisted fibres and evidence from Akrotiri, Thera. Światowit, 56, 75-88.

Vogelsang-Estwood G. (1999). The textile impression from Geraki. W: J. Weingarten, J.H. Crouwel, M. Prent, G. Vogelsang-Estwood, Early Helladic sealings from Geraki in Lakonia, Greece. Oxford Journal of Archaeology, 18.4, 357-376.

Weingarten J. (2000). Early Helladic II sealings from Geraki in Lakonia: Evidence for property, textile manufacture, and trade. W: W. Müller (red.), MinoischMykenische Glyptik. Stil, Ikonographie, Funktion. V. Internationales Siegel-Symposium, Marburg, 23.25. September 1999 (317-376). Berlin: CMS Beiheft 6. Weingarten J. (2018). Introductory remarks. W: M. Ameri, S. Kielt Costello, G. Jamison, S. Jarmer Scott (red.), Seals and Sealings in the Ancient World: Case Studies from the Near East, Egypt, the Aegean, and South Asia (327-333). Cambridge: Cambridge University Press.

Weingarten J., Crouwel J.H., Prent M., Vogelsang-Eastwood G. (1999). Early Helladic sealings from Geraki in Lakonia, Greece. Oxford Journal of Archaeology, 18.4, 357-376.

Weingarten J., MacVeagh Thorne S., Prent M., Crouwel J.H. (2011). More Early Helladic sealings from Geraki in Laconia, Greece. Oxford Journal of Archaeology, 30.2, 131-163.

Younger J.G. (1991). A Bibliography for Aegean Glyptic in the Bronze Age. Berlin: CMS Beiheft 4.

Younger J.G. (2018). Aegean Bronze Age seal stones and finger rings: Chronology and functions. W: M. Ameri, S. Kielt Costello, G. Jamison, S. Jarmer Scott (red.), Seals and Sealings in the Ancient World: Case Studies from the Near East, Egypt, the Aegean, and South Asia (334-354). Cambridge: Cambridge University Press. 


\author{
TEXTILES AND SEALS: ABOUT THE RELATIONSHIP BETWEEN TEXTILE \\ PRODUCTION AND SEALING PRACTICES IN BRONZE AGE GREECE \\ AND NEW EVIDENCE FROM THE CASTS OF TEXTILE IMPRESSIONS ON CLAY
}

\author{
SUMMARY
}

Due to preservation conditions, the evidence of excavated textiles from Bronze Age Greece is extremely limited in number and variety. However, the significant socio-economic role of textile manufacture has been acknowledged on the basis of indirect evidence of textile tools, especially clay spindle whorls and loom weights, iconography, especially frescoes, and Linear B documents. Furthermore, textile technology and patterns of transmission of knowledge and skills have been investigated using comparative data provided by ethnographic research and experimental archaeology. However, the importance of seals and sealing practices in relation to textile production has yet to be investigated in detail. This apparent gap in knowledge has become the main focus of the research project "Textiles and Seals. Relations between textile production and seals and sealing practices in Bronze Age Greece", funded by the National Science Centre of Poland and the Programme SONATA 13. The project aims to explore in particular the following phenomena: 1) notation practices on textile tools, specifically the practice of seal-impressing on loom weights; 2) textile production-related motifs in the iconography of seals; 3) use of textiles in sealing practices, as a means to tie, wrap, and hang the sealed objects. The evidence of textile impressions on the undersides of clay sealings is the main topic of this contribution. A unique collection of modern silicone and plasticine casts of the undersides of lumps of clay stamped by seals is stored in the Archive of the Corpus der minoischen und mykenischen Siegel (CMS) in Heidelberg. The substantial number of casts bearing imprints of textiles, cords, ropes and other organic products, such as mats, wickerwork and thongs, are currently being analyzed as part of the "Textiles and Seals" project.

Impressions of threads, cords and fabrics on clay, i.e., on pottery and sealings, are commonly considered an important and reliable source of knowledge about the qualities of actual textiles. However, the number and accuracy of data to be retrieved from a textile impression vary according to clearness, preservation, as well as the qualities of the clay fabric. Several tests with experimental impress- ing of textiles on clay were undertaken by the author prior to examination of the casts stored in the CMS, in order to determine other factors having a possible impact on the readability of impressions. Altogether seven samples of impressed threads, twined and woven textiles, and a piece of sprang were imprinted on clay as negative and positive impressions (i.e., clay imprints from the negative impressions on clay, Fig. 2). The choice of samples aimed at achieving a better understanding of how different raw materials and textile structures may affect the readability of impressions. The summarized observations are presented in Table 1. As a result, it can be suggested that higher three-dimensionality of the actual textile, its elasticity and the nature of the raw material it was made of, are important factors influencing the clearness and accuracy of impressions on clay. Measurements taken from the impressed samples differed from the original measurements, being both diminished and enlarged as compared to actual textiles. Therefore, all measurements taken from the CMS casts and discussed below should be considered approximate.

Textile impressions on clay are also considered a potential source of information on raw materials. Although a general distinction of plant fibres and wool seems to be possible on the basis of imprints, more specific identification of fibres, such as whether they are flax, hemp, bulrush, lime bast, etc., if possible at all, is problematic (Fig. 5). Moreover, animal products, such as guts and sinews are difficult to distinguish from plant fibres, e.g., tree bast or flax accordingly. It is possible, though, to identify a series of features characterizing the major classes of fibres and organic products, such as fibrous stems, tree bast, sinews, guts and leather, which can possibly be retrieved from their imprints on clay (Table 2, Fig. 5). These features describe the general microstructure and appearance of fibres (e.g., single fibres, strands, band-like appearance, length of fibres), smoothness of their surface and shape of the section, appearance of the endings, characteristic use-wear, and breakage pattern. The presence of several characteristic features on an individual textile impression may allow 
a less subjective fibre identification. However, it should be noted that several of the discussed features are similar for fibres of different type and origin.

To date within the "Textiles and Seals" project, 227 textile imprints on the undersides of clay sealings from the CMS Archive in Heidelberg have been documented and examined. The overall number of casts with textile impressions still awaiting investigation is estimated to be about 1,600 examples. The new data coming from the textile impressions on the CMS casts are handled and searched in a "Textiles and Seals" online database scheduled in and for the project. The database was built by the Digital Competence Centre of the University of Warsaw and its first module has been published online in March 2021 (https://data. textileseals.uw.edu.pl/iconography/search). The software used to construct the database is free and open source. The application tailored to the requirements of the database was written in Python, using the Django framework. Data is stored in a PostgreSQL database. The search and data visualization interface was built on the basis of Bootstrap. The scope of data referring to imprints of textile products on the undersides of clay sealings is comprehensively recorded for the first time and accessible through the search engine and exportable through Excel format file facility.

The textile imprints discussed in this contribution come from two sites in Bronze Age Greece: Early Bronze Age Lerna in Argolid and Middle Bronze Age Phaistos on Crete. Both were important administration centres with similar sealing practices, albeit located in distant times and various socio-cultural contexts. The sealing practices comprised repetitive sealing and opening of rooms and various objects in a daily administrative routine. The sealings occurred on wooden doors, pegs or knobs from sides of chests and other containers, as well as the coverings of jars and baskets (Fig. 1). The impressed textiles and organic products comprise threads, cords, thongs, fabrics, baskets, mats and wickerwork.

On casts from Lerna, 42 cord impressions are preserved, mostly S-plied. Diameters are measurable for 37 cords and range from 2.41-7.03 $\mathrm{mm}$, however most of the impressed cords (29 examples) falls in a more narrow cluster of diameters between 3-5 mm. This and the observed uniformity in the twist angle, ranging from 20-50 degrees on 27 examples, suggests a preference for using cords of similar qualities, most likely reflecting their functionality in wrapping and tying. But it can also suggest a certain degree of standardization of cord production at Lerna. At Phaistos, threads (22 examples), cords (82 examples) and thongs (nine examples) were used for tying and wrapping (Fig. 6). Plying is the most frequent technique for making cords, but although S-plied cords prevail, there are also three examples of Z-plied cords, while threads are mostly single z-spun. Six imprints of cords and four threads suggest braiding as a new technique (Fig. 7), unknown amongst the cord impressions from Lerna. Again, a large cluster of cords of 0.2-0.4 $\mathrm{mm}$ in diameter (73 examples) suggests a certain functional and perhaps technical uniformity of the cords used at Phaistos.

Fabrics were commonly used to protect the rims of jars, but this type of clay sealing was not very frequent at Lerna and Phaistos (30 examples altogether). Most of the textile impressions (163 examples, including dubious identifications), therefore, come from the small surfaces adjacent to pegs wrapped by cords and from flat surfaces at the edges of casts (Fig. 1). This peculiar pattern of appearance of such traces requires further experimenting in order to explain the origin of the textile imprints. However, it may be provisionally suggested that they occurred in a relation to the sealing practices rather than the sealed objects. They might have been accidental impressions of clothes worn by the individuals stamping seals or, perhaps, they were related to a practice of wrapping wet clay in fabric in order to keep it moist and elastic for sealing, or some manner of modelling of the lump of clay for an individual sealing the utilized fabric. The only weave recognized on the textile imprints is tabby. A possible decoration could have been preserved on the cast $\mathrm{PH}$ 697, where a thicker thread seems to be inserted into the open, netlike tabby weave at regular intervals (Fig. 8). The diameters of single threads were similar on the textile imprints from Lerna and Phaistos, and ranged from 0.19-0.56 mm and $0.15-0.91 \mathrm{~mm}$, respectively. The thread count has been occasionally estimated on the basis of short sections of 2 and $5 \mathrm{~mm}$ and it ranges from 20 to $80 \mathrm{t} / \mathrm{p} / \mathrm{cm}$, however a thread count higher than $40 \mathrm{t} / \mathrm{p} / \mathrm{cm}$ is known, though only from Phaistos.

The textile imprints on the CMS casts comprise new and exceptional evidence for threads, cords, fabrics, and other organic products used in storage and sealing practices in Bronze Age Greece. Due to the relatively large number of textile imprints, it is now possible, for the first time, to make site-specific comparisons of textile production on the basis of the products. The discussed evidence from Lerna and Phaistos proves more varied products and techniques in use at the latter. This may imply improvements in textile technology in the time-span of c. 750 years distancing both sites. However, given that clay sealings from Phaistos outnumber the evidence from all other sites in Bronze Age Greece, the broader range of textile impressions may also reflect more complex and advanced sealing practices at this prepalatial site. Finally, differences in the manner of tying and wrapping of the sealed objects provide new data for 
studies on Aegean sealing practices. Distinguishing characteristic manners of tying and wrapping can contribute to studies on how many individuals were involved in the sealing practices, how many seals might have been used or owned by an individual, and how many objects were indeed subject to sealing at a specific site.

Otrzymano (Received): 4.01.2021; zrecenzowano (Revised): 14.03.2021; zaakceptowano (Accepted): 19.03.2021

Adres Autorki:

Dr hab. Agata Ulanowska

Wydział Archeologii, Uniwersytet Warszawski

Krakowskie Przedmieście 26/28

00-927 Warszawa

e-mail: a.ulanowska@uw.edu.pl

iD https://orcid.org/0000-0002-4946-2711 
